\title{
APONTAMENTOS PARA UMA TEORIA GERAL DA EMPRESA: UMA VISÃO PRAGMÁTICA
}

\author{
Carlos Maurício Sakata Mirandola \\ Aluno do Curso de Graduação da Faculdade de Direito da \\ Universidade de São Paulo \\ "L'impreditore si è, l'impresa si governa, \\ l'azienda si ha."
}

Mario Ghiron

Resumo:

A emergência de fenômenos relacionados com a empresa, que extravasam a concepção dada pelo ordenamento corporativista italiano, faz com que surja a necessidade de se repensar sua natureza jurídica. Considerando-se que a empresa não é regida apenas pela lógica econômica (representada no Direito pela tríade contrato-propriedade-profissão), mas também por princípios publicísticos de proteção ao direito de livre iniciativa e concorrência, direitos difusos (consumidor e meio ambiente) e função social da propriedade, a quebra da concepção que emergiu do ordenamento italiano nas décadas de 40 e 50 e que inspirou nosso Projeto de Código Civil faz com que surjam novos perfis observáveis na noção de empresa que devem ser trabalhados para aplicação doutrinária.

$\mathrm{O}$ que se quer aqui é apresentar idéias sobre como rever essa noção, de forma a perceber a natureza da empresa e das relações sociais tuteladas pelo direito que a integram. Para isso, apresenta-se um panorama da doutrina (item 2), um método de trabalho (item 3) e, por fim, uma análise composta de uma série de distinções e classificações, baseadas em núcleos de sentido.

\section{Abstract:}

The emergency of phenomena related with the company that extravasate the conception given by the Italian collectivist ordenment does with that the need appears of rethinking your juridical nature. Being considered that the company is not just governed by the economical logic (represented in the Law by the triad contract-property-profession), but also for publicist principles of protection to the right of free initiative and competition, diffuse rights (consumer and environment) and social function of the property, the break of the conception that emerged of the Italian ordenment in the decades of 40 and 50 - and that inspired our Project of Civil Code - does with 
that new profiles appear you observed in the company notion that should be worked for doctrinaire application.

What is wanted here it is to present ideas on how to review that notion, in way to notice the nature of the company and of the social relationships tutored by the right that integrate her. For that, comes a panorama of the doctrine (item 2), a work method (item 3) and, finally, an analysis composed of a series of distinctions and classifications, based on nucleus sense.

Unitermos: empresa; natureza jurídica; visão pragmática.

\section{Premissa}

O problema de definir o conceito de empresa para o Direito aparece como uma forma de indicar em que medida se pode oferecer o grau de segurança da chancela jurídica a determinado fato, determinada noção de origem econômicosocial a que chamamos empresa. Asquini apresenta-a como ...um fenômeno econômico poliédrico, o qual tem, sob o aspecto jurídico, não um, mas diversos perfis em relação aos diversos elementos que o integram."

Observem atentamente esta definição; em primeiro lugar, coloca-se a idéia de fenômeno econômico poliédrico. O que isso significa? Podemos pensar, de pronto, em algo que escapa a simples cortes epistemológicos. Cortamos, para entender e utilizar, determinado tecido de um "organismo" social e o entendemos como um conjunto (portanto unidade), no qual seus constituintes apresentam algum tipo de relação. Vai de encontro com a segunda parte da definição: seus diversos elementos podem, portanto, ser apresentados na forma de uma diversidade de perfis, ou seja, facetas, cortes, dos quais se pode identificar características do fenômeno inteiro e, mais, utilizar em substituição ao todo.

Notou o comercialista italiano que as diversas noções jurídicas (portanto as reconstruções normativas do fenômeno empresa) não eram propriamente conflitantes mas, longe disso, apresentavam-se como conjuntos dos elementos mais importantes para a finalidade de alguma norma específica. Em outras palavras, considerou ele que o legislador, ao querer que uma razão, forma ou conseqüência 
fosse de algum modo imputada à empresa, decidiu por salientar um conjunto de elementos que fossem relevantes a seus objetivos.

Isso leva a dois resultados: (1) cada perfil não se destaca de seu fenômeno-base (único), e (2) que, de outra forma, devem ser observados os elementos e as condições dadas pelo legislador, quando da estipulação da lei.

Em segundo lugar, separam-se aqui dois momentos: um econômico, ao qual pertence a figura da empresa como um todo, e o outro jurídico, ao qual se reportam os diversos perfis. A pergunta que cabe aqui é: com eles se articulam, sabendo-se que devem reger-se por regras diferenciadas?

\section{Doutrina - panorama}

Para responder ambas as perguntas, precisamos recorrer às definições de empresa em ambos os mundos. Ferri começa por enunciar que a predisposição dos bens ou dos serviços ao mercado em geral não é uma atividade acidental e improvisada, mas especializada e profissional, a qual se explicita, através de um organismo econômico, propositadamente predisposto. ${ }^{2}$

Identifica-se aqui uma atividade, por um lado, e uma organização, por outro, unidos na direção de uma finalidade, indicada pela predisposição, e executada de forma profissional. Tal conceito nos serve como ponto de partida.

A doutrina apresenta de diversos modos essa realidade. Já lembrava Oscar Barreto Filho ${ }^{3}$ que a noção de empresa e seus reflexos no Direito Comercial foram esmiuçados por escritores de escol. Nada mais condizente com o objetivo de dar um pequeno panorama da matéria do que se começar com definições clássicas. Elas giram em torno da diferenciação dos fenômenos correlatos, como empresa, empresário, empregados, capitalistas, estabelecimento comercial e atividade.

\subsection{Empresa e estabelecimento}

$\mathrm{Mossa}^{4}$ identifica totalmente empresa com estabelecimento, não vendo os dois senão como momentos na evolução jurídica. Santoro-Passarelli ${ }^{5}$ vê entre

2. Ferri, Manuale de Diritto Commerciale, Torino, 1960.

3. Barreto Filho, Oscar. Teoria do estabelecimento comercial.

4. Trattato del nuovo Diritto Commerciale, p. 337 e nota 3.

5. L'impresa nel Codice Civile, in Rivista de Diritto Commerciale, 1942, I, p. 390. 
ambos uma relação de gênero (estabelecimento) e espécie (empresa, estabelecimento comercial estável, produtivo, de grandes ou médias proporções). Greco ${ }^{6}$ faz o mesmo, mas em outro sentido: espécie é o estabelecimento, parte do gênero empresa. Ghidini $^{7}$ vê, de outra forma, o estabelecimento como uma universitas facti e a empresa como universitas juris. Já Maroi ${ }^{8}$ entende que a empresa não é nada mais que a "forma de exercício do estabelecimento"

Carneluttii ${ }^{9}$ insere a questão do tempo: vê nos dois termos uma diferença de momento, sendo a empresa o aspecto dinâmico e a fazenda o estático. Ferrara Jr. ${ }^{10}$ nos traz também a idéia de que se deve interpretar a lei, dizendo algo do emprego figurado ou impróprio impregnado na letra. Na verdade, fazenda seria organização produtiva que constitui capital e empresa, a atividade profissional do empresário; qualquer uso fora dos padrões deveria ser interpretado como um descuido do legislador (melhor, imprecisão), a ser revisto e entendido devido ao sentido e direcionamento dado pelo texto.

Waldemar Ferreira tem uma concepção sistemática da relação entre empresa, empresário e o fenômeno jurídico; afirma que a "diferença entre empresa, estabelecimento, quando não se fundem, é o grau' Imagina, dessa forma, círculos concêntricos, aos quais relacionam os conceitos. O estabelecimento é circunscrito à empresa que, por sua vez, o é à pessoa natural ou jurídica, mercê de cujas vontades aqueles dois se movimentam. O estabelecimento está no centro, formado de bens corpóreos e incorpóreos, uma universalidade de fato. A empresa sobrepõe-se como organização de trabalho e disciplina da atividade no objetivo de produzir riqueza e de pô-la em circulação econômica. Tudo isso, porém, se subordina à vontade e às diretrizes traçadas pela pessoa, natural ou jurídica, que a haja organizado, sujeito ativo e passivo das relações jurídicas, tecidas pela empresa, no funcionamento do estabelecimento produtor de lucros pelo comerciante, como empresários, procuradores e obtidos. ${ }^{11}$

6. Apud Ferrara Jr., F. La teoria giuridica dell'azienda. n. 34, p. 89.

7. Disciplina giuridica dell'impresa, 1950.

8. Apud Roberto Bracco, L'impresa nel sistema del Diritto Commerciale, 1960, n. 47.

9. Sulle nuove posizione del Diritto Commerciale, in Rivista de Diritto Commerciale, 1942, 1, p. 68 .

10. La teoria giuridica dell'azienda, 1945, n. 34 .

11. Tratado de Direito Comercial. VI, n. 1.226, pp. 86-87. 
2.2. Empresa e empresário, empresa e atividade

Nesse último caso, ataca-se uma segunda imbricação, que é o conceito de empresário visto como relacionado ao de empresa. Barbero observa que o Código Civil italiano, embora fale de empresa, define apenas o empresário. Orientação semelhante assume o Projeto de Código Civil brasileiro:

Art. 969. Considera-se empresário quem exerce profissionalmente atividade econômica organizada para a produção ou a circulação de bens ou de serviços.

Parágrafo único. Não se considera empresário quem exerce profissão intelectual, de natureza científica, literária ou artística, ainda com o concurso de auxiliares ou colaboradores, salvo se o exercício da profissão constituir elemento de empresa.

Exegese: São elementos dessa definição (1) um sujeito quem ou coletividade deles definidos como pessoa física ou jurídica inscrita na forma da lei com devido procedimento, descritos nos arts. 969 a 983. No caso do Projeto, apesar do direito de empresa ser também caracterizado pelo empresário (veja a ênfase dada nos itens que dizem respeito às sociedades: no livro II - direito de empresa, o capítulo II da sociedade é o mais extenso e minucioso), podem existir empresas cujo empresário não seja pessoa sequer personificada. Jorge Rubem Folena de Oliveira $^{12}$ vê nisso um desenvolvimento da teoria da empresa e o fim da distinção entre sociedades civil e comercial. Pensa, nessa linha, que a noção de empresa, como organização de fatores de produção para criação ou circulação de bens e serviços, deve prevalecer sobre a de existência de um objeto que deva ser intrínseco ao comercial, ou um ato específico, praticado por dada pessoa ou tendo intuito comercial.

Waldírio Bulgarelli ${ }^{13}$ afirma que o Projeto marca o abandono do sistema tradicional consagrado no Código Comercial atual, baseado no comerciante

12. Desenvolvimento da teoria da empresa e o fim da distinção entre sociedades civis e comerciais. In Boletim Legislativo Adcoas, 1997. N. 4, 10 de fevereiro.

13. Tratado de direito empresarial, São Paulo, Atlas, 1995. 
e no exercício da mercancia, trocando-o pela adoção de um sistema do empresário e da atividade empresarial. Ainda menciona a exposição de motivos de Miguel Reale: ${ }^{14}$ "o tormentoso e jamais claramente determinado conceito de ato de comércio é substituído pelo de empresa, assim como a categoria de fundo de comércio cede lugar à de estabelecimento" A observação que se pode fazer, no momento, é de que cairíamos numa nova tautologia com a permanência da definição dos "atos empresariais" Definir empresa com relação aos atos empresariais para depois defini-los como atos praticados por empresas é um círculo vicioso, um truísmo, só superável com a exposição de jurisprudência - casos julgados que já tenham contraposto à realidade o conceito de empresa, produzindo Direito. ${ }^{15}$

(2) exercício profissional: para que se torne profissional, as exigências comuns incluem não ser esporádica e ser feita com o intuito lucro. Aprofundando-se na estrutura de trabalho da sociedade contemporânea, poderia-se lembrar dos quesitos de produção para o mercado (não é de auto-subsistência, mas direcionada à acumulação), com as devidas técnicas e melhoramentos, ritmo industrial e escala de massa (como definição-síntese do fenômeno na economia contemporânea). A noção sociológica de profissão traz consigo a idéia de papel social. Vide infra.

(3) atividade: seqüência de atos interligados, orientados teleologicamente (com determinado fim), direcionados a cumprir o fim de produção para o mercado.

(4) econômica: diz respeito ao enfrentamento do problema da escassez organização dos fatores de produção para otimização dos recursos naturais e humanos, de forma a tornar mais eficiente a alocação dos fatores de produção. ${ }^{16}$ Implica, portanto, em problemas relacionados com mercadoria, distribuição, relações de trabalho, propriedade, consumo, processos... enfim, um rosário de termos econômicos que muitos economistas teriam dificuldades em definir e dizer como eles se relacionam entre si. Considera-se a produção de riqueza e o direcionamento ao mercado como essenciais.

14. Exposição de Motivos do Projeto de Código Civil, Brasília, Ed. do Senado, 1989. Apud, Jorge Rubem Folena de Oliveira.

15. Vide Verçosa, Haroldo Malheiros. Ato de comércio. Mercancia. Matéria de Comércio. Comerciante, in Revista de Direito Mercantil, n. 47.

16. Heilbroner, Robert. A história do pensamento econômico. Trad. de Teresinha M. Deutsch, São Paulo, Nova Cultural, 1996. 
(5) organizada: existem duas possíveis abordagens a essa expressão: a. relativa ao sentido do termo, que pressupõe uma organização, uma estrutura nos moldes racionais, com instrumentos de controle, processos e procedimentos próprios, seqüência e divisão de competências e funções, com hierarquização rígida ou mais maleável da cadeia; ou b. relativa à flexão do verbo, particípio passado trazendo consigo a idéia de um sujeito ativo elíptico (já que a frase está na voz passiva). Indica a existência de um sujeito de direito, ligando-se à teoria do empresário, como responsável pela atividade empresarial. Veremos a seguir; por hora, lembremos apenas que ambas as noções juntas trazem consigo a idéia de profissionalismo, que embebe a atividade empresarial; o que acontece é uma demarcação de função social, como reflexo da divisão de trabalho imposta pelo sistema produtivo.

(6) para a produção de bens ou serviços: indica a finalidade da atividade. Não se menciona o lucro conjuntamente, cabendo a ressalva de que o novo texto consagra a "função social da empresa"; não cabe a nós neste momento nos alongarmos no assunto.

(7) há uma restrição quanto ao tipo de atividade que se possa exercer não pode ter sua natureza na pesquisa científica nem literária ou artística, a não ser que seja subsidiária. Esse elemento dá o objeto dos atos empresariais por definição $a$ contrario sensu, negativa.

O resultado final da atividade tem que ser comercializável no sentido de ser res in comercium, numa acepção um pouco diferente da romana, que inclui como requisitos não ser produto único e especial, portanto passível de ser comercializado aparte da idéia de existência de seu criador-produtor (não ser fruto de atividade intuito personae).

\subsection{Ferri}

Ferri nos apresenta a empresa como organismo econômico, o qual se concretiza na organização dos fatores de produção e que se direciona à satisfação de interesses externos, mais precisamente das exigências do mercado em geral. ${ }^{17}$ Essa terminologia econômica nos oferece uma noção de empresário, que é aquele cujo interesse especulativo é observado pela atuação econômica da empresa. 
Portanto, nota-se na empresa sempre a emergência do gênio criativo e regulador do empresário; por isso, a empresa é necessariamente colada à pessoa do empreendedor. Ela conserva por certo tempo o impulso recebido, mas este se dilui no funcionamento cotidiano. Deste modo, para se definir empresa deve-se definir o empresário e, então, chegar à sua atividade. Dificuldades nesse sentido são muitas: identificar o empresário, devendo passar pela contraposição ao capitalista e ao empregado. O que define e diferencia o empresário de ambos são dois elementos: a. o risco e b. a iniciativa.

Apesar disso, há casos em que ambos não são identificáveis; o risco nas cooperativas e nas empresas socializadas está diluído entre os trabalhadores ou entre a população. No caso da iniciativa, ela pode ser imputada a diversos tipos de pessoas, físicas ou jurídicas e, no funcionamento cotidiano da empresa, deve ser vista como proveniente também dos núcleos gestores profissionais (administradores, portanto empregados) da empresa.

$\mathrm{O}$ aspecto mais interessante, por um ponto de vista econômico e técnico, que é o fenômeno produtivo, na opinião de Ferri permanece irrelevante para o Direito se circunscrito ao âmbito de uma só pessoa; a empresa não surge para o Direito como organismo unitário e autônomo nem do ponto de vista subjetivo nem objetivo (p. 35). Só quando vista como organização de atos, isto é, complexo de aspectos e de regras concretamente prepostas a seu funcionamento, a empresa tem sua individualidade e sua objetividade, estruturada como uma entidade orgânica baseada num princípio ordenante e hierárquico, em torno da iniciativa do empreendedor (p. 36).

Toda tentativa de cindir ambos os termos, empresa e empresário, na visão do italiano, naufragaram não tanto frente à realidade econômica quanto frente à positivação. A organização da atividade é pressuposto da noção de empresário (art. 2.082 do Código Civil italiano) e a organização de bens ou obras do empresário é elemento da noção de estabelecimento (p. 38).

Há de se dar valor à noção de atividade, que a lei define como a destinação funcional e orgânica dos bens, criando e caracterizando a fazenda, mas também que cria os aparatos e regula como se deve presidir seu funcionamento. A organização resguarda a atividade, não os bens; não são os bens que asseguram o estabelecimento enquanto organizado pelo empresário, mas este que se define como tal enquanto titular do direito sobre o complexo aziendal, que vem qualificado como 
direito sobre a empresa o direito sobre a empresa é algo distinto do direito sobre a propriedade aziendal.

São partes, portanto, da definição de Ferri: a. a empresa como expressão da atividade do empresário; b. a empresa como idéia criadora; c. a empresa como complexo de bens; d. a empresa como conjunto de relações com seus dependentes, todos esses aspectos tutelados por uma disciplina publicística da ordem econômica.

\subsection{Ascarelli ${ }^{18}$}

A sistemática italiana (citando o mesmo art. 2.082 do Código Civil) também vê necessidade de definição do empresário para se identificar a empresa. Sendo empresa atividade, o que caracteriza o empresário é a atividade econômica. É a natureza e o exercício da atividade que qualificam o empresário (e não o contrário, a qualidade do sujeito que define a atividade). Há, no Direito Comercial, a persistência de um elemento objetivo: a atividade e, portanto, a empresa. Define-se como:

a. significa série de atos (no sentido técnico-jurídico) coordenados entre si em função de uma finalidade comum têm valor instrumental imputáveis ao empresário. Os corolários dessa afirmação são (i) a proibição de uma atividade não-acarreta nulidade nem dos atos isolados, (ii) a nulidade pode fulminar a atividade (portanto o sujeito que a exerce) sem prejudicar os atos (em relação à validade para com terceiros) e (iii) a disciplina privatista dos atos pode permanecer independente da publicista os atos de uma empresa podem ser enquadrados por normas de ordem pública e privada indiferentemente da atividade ser pública ou privada;

b. a atividade deve ser apreciada de modo autônomo: atos podem ser classificados nas díades válido/inválido, existente/inexistente, simulado/real, mas a atividade somente em lícita/ilícita, regular/irregular, real/aparente (o que faz que a atividade não-exclua a imputabilidade, acarretando sanções ao responsabilizado);

c. a falta de habilitação do sujeito persegue a atividade, já que a aquisição de titularidade da empresa tem requisitos que devem ser cumpridos para (i) proteger o próprio sujeito ou (ii) a atividade em si;

18. Corso de Diritto Commerciale, pp. 145 e ss. 
d. O sujeito é o termo de imputação jurídica da atividade, portanto o empresário é a figura à qual se imputa a empresa. Sujeito dos atos singulares que formam a atividade é um conceito jurídico, não-econômico; nele não se encontram noções de direção e risco, no sentido material, mas as conseqüências delas para o ordenamento. Corolários: (i) a certeza de aplicação requer tipificação, (ii) isso faz com que o tipo possa não-permanecer constante, (iii) risco, lucro e organização devem vir na forma da lei não como conceitos econômicos e (iv) podem assim serem encarados: risco necessidade de adimplemento das obrigações perante terceiros, iniciativa (organização) vontade juridicamente relevante para a conclusão de negócios, lucro - imputação de responsabilidade por resultados de atos jurídicos. O empresário, em verdade, adquire direitos e obrigações provenientes da atividade empresarial. No mundo jurídico podem não-coincidir com as relações do mundo real. Na realidade econômica, o lucro pode ser imputado ao capitalista ou ao empresário, ou a ambos; a direção ao empresário e aos diretores (funcionários). $\mathrm{Na}$ realidade jurídica, primariamente tudo se imputa ao empresário, que pode ser subsumido em diversos entes, dependendo da definição legal em cada caso;

e. a pessoa física tem natureza diferenciada da pessoa jurídica: a atividade só pode ser imputada à pessoa jurídica se obedecer ao escopo como, por exemplo, no caso do sócio de responsabilidade ilimitada, que é sujeito à falência pessoal por via de extinção da sociedade inadimplente, mas não por seus próprios débitos pessoais (na concepção do ordenamento italiano);

f. a atividade é fato para cuja vontade do sujeito é juridicamente irrelevante; desta vontade não dependem as conseqüências jurídicas nem a subsistência da empresa;

g. a atividade se desenvolve no tempo, tem início, fim e localização. No caso do empresário pessoa física, podem ser identificados como os da pessoa mesma empresária; no caso da pessoa jurídica empresária, como os do escopo;

h. atividade não tem destinatário específico (é dirigida ao mercado ou para consumo próprio do empresário);

i. do exercício (pessoa física) ou do escopo (pessoa jurídica) deriva uma qualificação do sujeito;

j. esta é o pressuposto para aplicação da disciplina especial do Direito Comercial;

1. essa qualificação é adquirida e não pode ser transferida a outro empresário; 
m. empresário não constitui um status jurídico diferenciado;

n. podem-se qualificar os atos de administração como ordinários e extraordinários, de acordo com a relação deles com o exercício da atividade;

o. outra classificação: atividade autônoma e subordinada (esta última se exerce na dependência de outrem e cujos resultados vinculam-se a bens alheios ou são serviços fornecidos por outras pessoas. Exemplos: profissionais autônomos e empresários exercem atividade autônoma; empregados, subordinados). Isso gera a emergência de regulação de caráter publicístico, para que se possa equilibrar o jogo de forças.

A atividade do empresário define-se por:

a. ser econômica criadora de riqueza, vista como bens e serviços patrimonialmente valoráveis. Exemplos: agricultura, indústria, especulação financeira. Não é mero gozo, ainda que este possa acontecer sob uma estrutura de administração e gestão; só é econômica se há direcionamento para outro ente do produto da atividade, para o mercado. O exercício da fazenda implica num nãoconsumo particular do bem ou serviço produzido;

b. direcionada à produção e ao escambo: o titular da atividade deve ser diverso do destinatário último do produto. Implica na existência e enfrentamento da concorrência, já que a atividade do empresário é sempre direcionado ao mercado (p. 166). A noção geral de empresa encontra sua justificação sobre o terreno da concorrência e na disciplina publicística da economia;

c. o objeto da atividade deve ser coisa ou serviço, portanto estão excluídas as atividades intelectuais. As últimas têm definições jurídicas e condições de exercício rigorosas. Falta, nesses casos, a organização, razão esta por que não se enquadram no fenômeno empresarial. A despersonalização, que de certa forma é decorrente da atividade organizada, não-acontece neste caso por causa do intuito personae das atividades; o acesso ao mercado e a produção e oferta de serviços têm uma valoração social diversa, que importa em não-incluir o exercício das profissões intelectuais do âmbito dos empreendedores (p. 170);

d. atividades auxiliares são desenvolvidas também por empresários comerciais. O que dá a característica de auxiliar não é tanto a concatenação com a atividade comercial (principal) propriamente dita, mas a própria natureza da atividade (auxiliar) exercida;

e. a atividade empresarial tem uma finalidade lícita que, de outro modo, se trataria sempre de uma atividade imputável, mas não mais empresarial; 
f. a atividade deve ser organizada, mas a organização deve ser entendida independentemente de um complexo de bens (estabelecimento ou fazenda). O trabalho em si não é empresa; diferencia-se o empregado (trabalhador) do empresário sabendo que ambos exercitam objetivamente uma atividade, mas juridicamente não se imputa a produção de bens e serviços ao primeiro.

\subsection{Casanova:}

"L'imprenditore è un soggeto; l'impresa è un'attività da lui o per lui, organizatta o svolta; l'azienda, lo strumento del qual l'impreditore o chi opera in suo nome e per suo conto, si serve per esercitare l'impresa'. ${ }^{19}$ Nessa definição, são requisitos para o art. 2.082 do Código Civil italiano:

a. profissionalidade - sistemática que imprime naquele que a exercite uma qualificação social, status sendo, portanto, derivada da única ou principal atividade que o sujeito empresário realiza. Não é necessário que seja ininterrupta. A profissão é um fenômeno social, no qual se reflete o princípio da divisão de trabalho. No caso do produto da atividade, é necessário que seja destinado ao escambo, que o empresário trabalhe para o mercado de outro modo seria empresário no sentido econômico, mas não jurídico;

b. organização de atividade econômica cujos produtos sejam destinados ao escambo - a atividade não pode ser personalista, o trabalho do empresário é tipicamente de organização de caráter patrimonial e trabalho de outrem;

c. o lucro não é elemento essencial do empresário, mas da empresa, por ser essa a forma que este organismo tem para prosperar (cita Mossa: o escopo do exercício, escopo de faturar, não tem valor específico para a formação da figura do empresário comerciante... Não é dela [da figura do empresário] a intenção de lucro, mas do organismo comercial da empresa que se pega na conclusão da qualidade de comercial.) (p. 80, nota de rodapé). É visível na empresa pública essa diferenciação: a falta de um elemento positivo de receita é compensada pela presença negativa da repartição de despesa. Já que prescinde do empresário privado para executar a atividade, obedece-se ao princípio do menor custo social, 
conseguindo, assim, o resultado lucrativo da empresa; o lucro está na atividade custar menos para a sociedade, não nos dividendos do empresário (Estado).

É, pois, empresário, no sentido jurídico, aquele em nome do qual cumpre-se a atividade organizada na forma de empresa, participando ele diretamente ou indiretamente. É responsável perante terceiros e esta responsabilidade comercial, em regra, absorve o conceito de risco econômico. Mas não é exigência que tal seja assim, é coincidência.

É necessária, de outro modo, a efetividade do exercício da atividade; não-basta anunciar publicamente e registrar a empresa em seu nome. Tal critério aplica-se apenas à pessoa física, já que a jurídica se forma em torno de um escopo, não de uma vontade.

Por fim, define-se empresa como todo exercício profissional de uma atividade organizada, com fim de produção e escambo de bens e serviços. ${ }^{20}$ É suporte da figura jurídica do empresário, como resguarde da profissionalidade e exercício efetivo; é destinada à troca, ao mercado; essencial ao menos o intento de lucro. A empresa não se extingue, mas continua com um novo empresário, substancialmente imutável, se continua a mesma organização real e pessoal, prosseguindo no mesmo escopo, na obra em curso, na relação preexistente. Forma uma realidade discriminada e distinta, organização econômica de pessoas, relações e bens. Não é necessário que estabelecimento e empresa tenham o mesmo dono, apenas que se faça uso daquele pelo mesmo sujeito. Nesse sentido, o conceito de estabelecimento é correlativo ao de empresa, quando constitui um complexo de bens que são instrumentos do trabalho do empresário - portanto, a projeção patrimonial da empresa.

20. Há de se observar, na opinião do comercialista italiano, que a relutância da doutrina em exaurir a noção de empresa no conceito de atividade empresarial é determinada pela impressão que, de tal modo, se a traduziria o coeficiente organização no fenômeno empresa, que é uma definição incompleta. É certo que a atividade empresarial se distingue das outras por causa desse coeficiente, ou seja, enquanto é tipicamente uma atividade organizatícia. O estabelecimento é essa atividade objetivamente concretizada o organismo técnico-econômico, mercê do qual a empresa atua e se desenvolve. Nesta forma, a confusão entre esses termos transparece em cinco casos na doutrina: a. a empresa como organização de pessoas, de colaboradores do empresário; o estabelecimento como complexo ou organização de coisas e bens, stricto sensu (Valeri, Salandra); b. empresa como organização de bens e pessoas; estabelecimento somente como de bens (Francheschelli, Greco, Santi Romano, Bigiavi); c. ambos como sinônimos (Mossa); d. empresa espécie de estabelecimento (Santoro-Passarelli); e. empresa e estabelecimento constituindo dois aspectos, respectivamente subjetivo e objetivo, do mesmo fenômeno (Ferrarini) (p. 90). 


\subsection{Comercialistas brasileiros:}

Carvalho de Mendonça ${ }^{21}$ dizia que empresa é a organização técnicoeconômica que se propõe a produzir, mediante a combinação dos diversos elementos, natureza, trabalho e capital, bens ou serviços destinados à troca (venda), com esperança de realizar lucros, correndo os riscos por conta do empresário, isto é, daquele que reúne, coordena e dirige esses elementos sob sua responsabilidade. Identifica como essenciais: a. uma série de trabalho e capitais, ou ambos combinados; b. uma série de negócios do mesmo gênero, de caráter mercantil; c. assunção de risco próprio da organização.

Rubens Requião ${ }^{22}$ faz de imediato uma observação: o conceito jurídico de empresa assenta-se sobre o econômico, mas em vão os juristas brasileiros tentam construir um conceito jurídico (p. 50). Acompanhando Ferri e, de certa forma, Ascarelli, afirma que a disciplina jurídica da empresa é a disciplina da atividade do empresário e a tutela jurídica da empresa é a tutela jurídica dessa atividade. Introduz, nesse momento, um panorama histórico que inclui:

a. Direito francês: conceito de empresa, no Código Civil, de 1807, era desenvolvido em torno da idéia prática de atos de comércio de massa, que se reporta à atividade metódica e profissionalmente organizada, visando a um fim lucrativo qualquer (Maurice Chevrier). É repetição de atos praticados a título profissional, de sorte que a concepção se apresenta como síntese da dupla noção do ato de comércio e de comerciante, que tem como conseqüência confundir os julgamentos que distingam o sistema objetivo da comercialidade do sistema subjetivo (Jean Escarra). A empresa, do ponto de vista jurídico, se confunde com a exploração, pois pouco importa que o comerciante explore com capitais próprios ou alheios, que poderiam ser emprestados ou adiantados (Georges Ripert). Em outra linha, tenta-se dissociar a noção de empresário da de empresa, dizendo que a última é todo organismo que se propõe, essencialmente, a produzir para o mercado certos bens ou serviços e que independe financeiramente de qualquer outro organismo (Michel Despax). Indicação clara do sentido atual da doutrina francesa: a personificação;

21. Mendonça, J. X. Carvalho de. Tratado de Direito Comercial brasileiro, Rio de Janeiro, Freitas Bastos, 1945, p. 493.

22. Curso de Direito Comercial, São Paulo, Saraiva, 1998, v. 1. 
b. Direito italiano: o moderno Direito italiano funda-se sobre a tẹria da empresa. Vivante identificou o conceito jurídico com o econômico, dizendo que ela é o organismo da economia que, sob seu próprio risco, recolhe e põe em atuação sistematicamente os elementos necessários para obter um produto destinado para troca. Rocco coloca o tema sobre a perspectiva de organização de trabalho, recrutado, organizado, dirigido, fiscalizado e recompensado pelo empresário para os fins de produção. O autor brasileiro então apresenta o cenário no qual se erigiu a concepção do Código italiano, de 1942, sob a égide do corporativismo fascista e discorre sobre a dificuldade dos doutrinadores para, a partir daí, criar seu conceito. Afora os autores tratados já aqui por nosso próprio punho, resta-nos colocar a opinião do comercialista a respeito de Ferrara: " a empresa supõe uma organizaçâo por meio da qual se exercita a atividade; todavia, o conceito de empresa não tem para ele, na realidade, relevância jurídica, pois 'os efeitos da empresa não são senão efeitos a cargo do sujeito que a exercita', isto é, do empresário";

c. Direito brasileiro: no Regulamento n. 737, de 1850, ao enumerar os atos de comércio, incluiu-se as empresas. Neste sentido, utilizou-se a definição francesa, de repetição de atos praticados, uma organização de serviços, que explore o trabalho alheio, material ou intelectual. "Intromissão se dá, aqui, entre o produtor do trabalho e o consumidor (...) com o intuito de lucro. (Inglez de Souza, nas palavras de Requião). Às vezes se chegou a concluir pela falta de elementos que, combinados com os econômicos, para a formação do conceito jurídico de empresa (Sílvio Marcondes Machado). Ou que, na realidade brasileira, as empresas pautamse essencialmente pela predominância do aspecto individual do empresário sobre os conceitos de atividade e instituição empresarial, sendo que a adoção de certas fórmulas francesa ou italiana seria deformar o, que acontece aqui (Francisco Campos). Rubens Requião, por último, ainda critica a comissão que elaborou o Projeto de Código Civil por se deixar "dominar pela timidez e perplexidade dos juristas italianos de 1942" e evitar "definir o conceito de empresa";

d. empresa como abstração: parte-se da premissa básica que é errôneo tratar a empresa como materialização. Percebendo-se nela uma abstração, aproveitase o argumento de Brunetti de que a relação entre pessoas e os meios de exercício não podem conduzir senão a uma entidade abstrata, devendo-se ligá-la ao empresário (seu titular). Soma-se o de Dalmartello: a empresa é caracterizada pelo exercício da organização produtiva. Sendo organização a conjunção entre o trabalho das pessoas, capital e o complexo de bens dispostos pelo empresário no sentido de produzir, 
chega-se que a empresa nasce apenas com a vontade materializada do mesmo. Conclui-se que exercício é uma abstração, como o é a empresa. Desse modo, a atividade pode ser objeto de tutela jurídica, a despeito da crítica de Orlando Gomes a essa possibilidade, o que transforma a empresa em objeto de direito.

Vera Helena de Mello Franco ${ }^{23}$ não-consegue escapar à noção de empresa como sendo de atividade (conjunto de atos direcionados a um fim) econômica-organizada. Faz-se a esses atos a exigência de requisitos positivos. A empresa, dessa forma, como conceito econômico, desdobra-se em "organização de fatores da produção (capital, trabalho e matéria-prima) para a produção de bens e serviços para o mercado" (p. 67). Sobre este, constróem-se os diversos conceitos jurídicos. A empresa interessa ao Direito Econômico enquanto organização da produção para o mercado ou simplesmente organização produtiva. Não é, portanto, sujeito de direitos (quem o é, é seu titular, o empresário), não tem autonomia jurídica e patrimonial em si mesma e somente algumas têm personalidade jurídica (apesar desta ser a atual tendência, segundo a autora). Nesse caso, precisa-se definir empresário, o que se faz com a idéia de sujeito do sistema econômico. Assim como o consumidor e o titular da força de trabalho, o empresário é sujeito e tem tutelas jurídicas a ele relacionadas. Por ele organizar os fatores de produção na atividade de intermediação, assume o risco econômico e a iniciativa do empreendimento, não se confundindo com o capitalista e com o titular da força de trabalho. Exerce a função de intermediário, especulando sobre a diferença entre o custo do capital e o trabalho no exercício da produção para o mercado, atuando em nome próprio na gestão de sua empresa. Não é especulador puro e simples "pois não desempenha uma atividade geradora de riquezas" (p. 89).

Theophilo Azeredo dos Santos, ${ }^{24}$ ao comentar a Lei n. 8.934, de 18 de novembro de 1994, diz que, pela conformação atual do Direito brasileiro, prevalece a atividade econômica da empresa para caracterizá-la como comercial. A velha discussão que dividiu os juristas entre os que ficavam presos às regras do Código Comercial (nota-se que este não-oferece um conceito jurídico de comerciante) para considerar mercantis os atos indicados na legislação do Império e os que preferem avalizar a tese da ampliação do conceito de empresa comercial. As sociedades

23. Lições de Direito Comercial - teoria geral do Direito Comercial, São Paulo, Maltese, 1995.

24. Comercialidade das sociedades de objeto civil, fins econômicos e lucrativos. In Caderno Especial n. 236, da Associação dos Bancos do Estado do Rio de Janeiro. 
estarão, em consequiência, sujeitas à falência e terão direito à concordata, pois são comerciais pela força de lei, cujo objeto social for a produção e a circulação de bens e serviços com ênfase para o setor de serviço, hoje marcadamente desenvolvido, especialmente após a chamada "terceirização" Na opinião do autor, a lei atingiu, ainda, as firmas individuais, cujos titulares serão considerados comerciantes individuais nos mesmos moldes acima estabelecidos.

Por partes: a afirmação de que prevalece a atividade econômica para caracterizar a atividade como comercial traz à tona duas observações: a. que existem outros tipos de empresas, caracterizadas por outros tipos de atividades; b. que a atividade passa a ser determinante à empresa, já que econômico diz respeito à comercial. Logo depois, indica que tal diferenciação é importante para o uso prático de identificação dos atos que são comerciais, não mais como no Código Comercial, no qual se identificavam atos por natureza comercial, não-deduzíveis da comercialidade da atividade. Mas, para daí estender os institutos da falência e da concordata a todas as atividades em que se presume dentro desse conceito ainda vago de comercialidade como organização, cujo objeto de atividade é comercial, isso é passo demasiado grande; tal definição ainda não é aceita por grande parte da doutrina, como observado.

\section{Análise}

3.1. Ponto de partida - a constatação metodológica de Asquini:

"Um é o conceito de empresa, como fenômeno econômico; diversas as noções jurídicas relativas aos diversos aspectos do fenômeno econômico." 250 conceito econômico captado pelo Código Civil italiano é aquele do ordenamento corporativo, de base profissional, do regime fascista - tal como empresa se refere essencialmente à economia de troca, naquele caso, a atividade do empresário pode adquirir caráter profissional. Será que tais premissas cabem ao nosso sistema jurídico contemporâneo (ou até o italiano de hoje em dia?). Note-se bem a data e a prudência do autor em perceber tal; vejamos: 
a. A ideologia corporativista ${ }^{26}$ que direcionou o Código Civil italiano daquela época final do fascismo teve fundamento numa concepção de sociedadeforça. Esta não era um simples agrupamento de indivíduos, mas um organismo ${ }^{27}$ que vivia: a imagem é do corpo humano que, longe de ser um amontoado de órgãos e tecidos, é algo distinto da soma deles, tendo uma característica única e maior. A força, a evolução, não-estava mais com o indivíduo, como era nas etapas históricas anteriores, mas agora com o grupo; a imagem preferida era o feixe (fasce, de onde fascismo). No Brasil, o símbolo dessa ideologia era a $\Sigma$, somatória... Nesse sentido, o Estado passa a ser o representante da Nação, o organismo supremo; as pessoas devem ser entendidas como órgãos do Estado, sendo que sua posição como indivíduos fica reduzida em importância; toma vislumbre o papel social dela na organização.

O Brasil hodierno cọnsagrou a noção de função social da propriedade: ${ }^{28}$ a função social inicialmente adstrita à limitação de $u$ so do solo e água (Lei n. 6.662, de 25.06.1979 e Decreto n. 89.496; de 29.03.1984 - dispõe sobre a Política Nacional de Irrigação) passou a valer no Estatuto da Terra (Lei n. 4.504) e todas as normas que o regulamentam (Lei n. 6.746, de 10.12.1979, Decreto n. 84.685, de 06.05.1980) como critério para desapropriação para, a partir de 1988, ser consagrada na Constituição Federal, de 1988, pelo art. $5^{\circ}$, XXIII e XXIV para a propriedade; ressalta-se o art. 156, III, § IV. que versa sobre o mecanismo tributário para fazer valer essa concepção; art. 170 (no capítulo da ordem econômica), que retoma a função social da propriedade, agora no aspecto econômico, inserindo-a no contexto dos princípios da atividade de produção (à qual se reporta nosso tema, a empresa); art. $5^{\circ}$ XXIX, para a utilização de marcas e patentes de invenção; art. 173, I, que dá os limites da intervenção estatal; art. $182, \S 2^{\circ}$, que dá os princípios da política urbana; art. 184 caput, da política agrícola fundiária. Também, a Lei n.

26. Repare bem na citação feita, de onde se retirou o conceito econômico: "Lezioni di economia corporativa" de Papi, "Economia politica corporativa" de Vito e "Economia politica corporativa" de Gerbino.

27. Para mais sobre a concepção de sociedade como organismo, ver Otto Von Gierke, La naturaleza de las associaciones humanas. Discurso proferido no ato de posse ao Reitorado da Universidade de Berlim em 15 de outubro de 1902; é direito real, portanto oponível erga omnes. Observe-se que a evolução do conceito, de essencialmente individualista do Direito Romano e Revoluções Liberais, até o atual (em que o titulo só é justo se tiver a utilização condigna com sua função social) traz consigo uma mudança de natureza do instituto muito importante.

28. Propriedade no sentido romano: usar, fruir, gozar e dispor da coisa. 
8.171, de 17.01.1991, dispõe sobre a Política Agrícola; Decreto n. 433, de 24.01.1992, dispõe sobre a Aquisição de Imóveis Rurais, para Fins de Reforma Agrária, por Meio de Compra e Venda; Lei n. 8.629, de 25.02.1993, dispõe sobre a Regulamentação dos Dispositivos Constitucionais Relativos à Reforma Agrária, previstos no Capítulo III, Título VII, da Constituição Federal.

O princípio passou a valer também nos assuntos diretamente relacionados à atividade empresarial; temos: Lei n. 8.884, de 11.06.1994, que transforma o Conselho Administrativo de Defesa Econômica - CADE em Autarquia, dispõe sobre a Prevenção e a Repressão às Infrações contra a Ordem Econômica e dá outras providências.

Título I - Das Disposições Gerais (arts. $1^{\circ}$ e $2^{\circ}$ )

Capítulo I Da Finalidade (art. $1^{\circ}$ )

Texto:

Art. $1^{\circ}$ Esta Lei dispõe sobre a prevenção e a repressão às infrações contra a ordem econômica, orientada pelos ditames constitucionais de liberdade de iniciativa, livre concorrência, função social da propriedade, defesa dos consumidores e repressão ao abuso do poder econômico.

Parágrafo único. A coletividade é a titular dos bens jurídicos protegidos por esta Lei.

A função social passa a ser o critério de interpretação das relações sociais:

Lei n. 9.126, de 10.11.1995 - Dispõe sobre a Aplicação da Taxa de Juros de Longo Prazo TJLP sobre Empréstimos Concedidos com Recursos dos Fundos Constitucionais de Financiamento das Regiões Norte, Nordeste e CentroOeste e dos Fundos de Investimentos do Nordeste e da Amazônia e do Fundo de Recuperação Econômica do Espírito Santo, e com recursos das Operações Oficiais de Crédito, altera Dispositivos da Lei n. 7.827, de 27 de setembro de 1989, e dá outras providências.

Art. $1^{\circ}$ A partir de $1^{\circ}$ de julho de 1995, os financiamentos concedidos com recursos dos Fundos Constitucionais de Financiamento das Regiões Norte, Nordeste e Centro-Oeste, de que trata a Lei n. 7.827, de 27 de setembro de 1989, terão como custo básico o Taxa de Juros de Longo Prazo TJLP

$\S I^{\circ}$ Os bancos administradores dos Fundos de que trata este artigo poderão, nas operações contratadas a partir de $l^{\circ}$ de julho de 1995, cobrar "del 
credere" compatível com os riscos assumidos pelos financiamentos concedidos $e$ adequados à função social de cada tipo de operação, adicionalmente aos custos previstos no "caput" deste artigo, de até seis por cento ao ano.

Lei n. 9.279, de 14.05.1996

Regula Direitos e Obrigações Relativos à Propriedade Industrial.

Título VIII Das Disposições Transitórias e Finais (arts. 229 a 244)

Art. 240 - $\mathrm{O}$ art. $2^{\circ}$ da Lei n. 5.648, de 11 de dezembro de 1970, passa a ter a seguinte redação:

Art. $2^{\circ}$ O INPI tem por finalidade principal executar, no âmbito nacional, as normas que regulam a propriedade industrial, tendo em vista a sua função social, econômica, jurídica e técnica, bem como pronunciar-se quanto à conveniência de assinatura, ratificação e denúncia de convenções, tratados, convênios e acordos sobre propriedade industrial."

A lei que disciplina os serviços de telecomunicações relaciona o princípio da função social à atividade de telecomunicações; isso é indicativo de que o ordenamento inclui a propriedade dos meios de produção no rol daquelas que devem se reportar à disciplina publiscística da propriedade.

Lei n. 9.472, de 16.07.1997

Dispõe sobre a Organização dos Serviços de Telecomunicações, a Criação e Funcionamento de um Órgão Regulador e outros Aspectos Institucionais, nos termos da Emenda Constitucional n. 8, de 1995.

Livro I - Dos Princípios Fundamentais (arts. $1^{\circ}$ a $7^{\circ}$ )

Texto:

Art. $5^{\circ} \quad \mathrm{Na}$ disciplina das relações econômicas no setor de telecomunicações observar-se-ão, em especial, os princípios constitucionais da soberania nacional, função social da propriedade, liberdade de iniciativa, livre concorrência, defesa do consumidor, redução das desigualdades regionais $e$ sociais, repressão ao abuso do poder econômico e continuidade do serviço prestado no regime público.

Livro III Da Organização dos Serviços de Telecomunicações

Título III Dos Serviços Prestados em Regime Privado

Capítulo I Do Regime Geral da Exploração (arts. 126 a 130) 
Art. 127 A disciplina da exploração dos serviços no regime privado terá por objetivo viabilizar o cumprimento das leis, em especial das relativas às telecomunicações, à ordem econômica e aos direitos dos consumidores, destinandose a garantir:

I. a diversidade de serviços, o incremento de sua oferta e sua qualidade;

II. a competição livre, ampla e justa;

III. o respeito aos direitos dos usuários;

$I V$. a convivência entre as modalidades de serviço e entre prestadoras em regime privado e público, observada a prevalência do interesse público;

$V$ o equilíbrio das relações entre prestadoras e usuários dos serviços;

VI. a isonomia de tratamento às prestadoras;

VII. o uso eficiente do espectro de radiofreqüencia;

VIII. o cumprimento da função social do serviço de interesse coletivo, bem como dos encargos dela decorrentes;

$I X$. o desenvolvimento tecnológico e industrial do setor;

$X$. a permanente fiscalização.

Livro III Da Organização dos Serviços de Telecomunicações

(arts. 60 a 185)

Título IV - Das Redes de Telecomunicações (arts. 145 a 156)

Texto:

Art. 146 As redes serão organizadas como vias integradas de livre circulação, nos termos seguintes:

I. é obrigatória a interconexão entre as redes, na forma da regulamentação;

II. deverá ser assegurada a operação integrada das redes, em âmbito nacional e internacional;

III. o direito de propriedade sobre as redes é condicionado pelo dever de cumprimento de sua função social.

Parágrafo único. Interconexão é a ligação entre redes de telecomunicações funcionalmente compativeis, de modo que os usuários de serviços de uma das redes possam comunicar-se com usuários de serviços de outra ou acessar serviços nela disponíveis. 
O novo princípio de função social da propriedade tem uma dupla característica: em primeiro lugar, retira o peso da concepção corporativista da empresa e do empresário por defender a idéia de propriedade individual (corolários: livre iniciativa, participação justa no mercado, competição). Por pregar a igualdade de chances, retira da concepção de status social e empresário (consequentemente), a posição de figura em torno da qual se articula o fenômeno empresarial para, em segundo lugar, dar a primazia sobre a articulação dos contornos de como se deve desenvolver a atividade; ${ }^{29}$

b. é claro que este não é o único conceito que serve para corroborar aquela concepção. Só a título exemplificativo, esse foi citado para justificar porque não se pode mais entender a empresa como fenômeno somente econômico, pelo menos para a aplicação jurídica. Ainda assim, salientamos que o método proposto por Asquini vai na direção certa, sob a óptica do Direito. Resta-nos explicar sua concepção:

\subsection{Asquini:}

A primeira parte de seu texto é dedicada à definição do fenômeno econômico da empresa, montado naquela premissa transcrita supra, para mostrar como o ordenamento italiano captou-o. Tal conceito refere-se essencialmente à economia de troca, pois somente nessa órbita a atividade do empresário pode adquirir caráter profissional. Retornando à doutrina italiana supracitada, percebe-se como se dá ênfase nessa questão; o fenômeno empresarial só pode ser explicado com recorrência às idéias de empresário e da profissionalidade da atividade, na idéia de organização. O risco, então, é definido como um suportar o adimplemento das obrigações perante terceiros (relação entre o resultado útil da empresa para o empresário e a responsabilidade a ele imputada de relações jurídicas) e o lucro surge como (i) motivação normal da atividade empreendedora e (ii) remuneração do empresário (prêmio) por seu risco e atividade organizatória.

29. Para uma discussão mais aprofundada sobre o assunto, ver: Dantas, Francisco W. L. Lineamentos jurídicos da empresa e o código do consumidor. In $R T$ v. 67, set. 1991, sobre a aplicação desse conceito no Direito do Consumidor; Wald, Arnoldo. O espírito empresarial, a empresa e a reforma constitucional. In Revista de Direito Mercantil, Industrial, Econômico, Financeiro, n. 98, abril-junho 1995, sobre a empresa na constituição; e, principalmente, Comparato, Fábio Konder. Estado, empresa e função social. In RT, v. 732, out. 1996. 
O caráter profissional da atividade do empresário é, nessa concepção, elemento natural da empresa, proveniente do princípio da divisão do trabalho. Em qualquer tipo de economia organizada, na opinião do autor, a empresa é célula fundamental, mais eficaz e mais útil no interesse da nação. ${ }^{30}$

O passo seguinte é, a partir da nova legislação (o Código Civil de 1942), estabelecer comparações com as legislações anteriores:

a. no Código Civil, de 1865 (que retratava o Código napoleônico), a empresa era a prestação do conductor operis (empresário, art. 1.627. n. 3) na locatio operis (contrat d'enteprise) ou um dos possíveis termos de referência para a determinação da operae advindas da locatur operarum o empresário era o fornecedor;

b. no Código Comercial, o conceito de empresa era o econômico, porém sob o perfil dos atos objetivos de comércio (prescindindo do elemento comercial) Ex.: art. $3^{\circ}$ ns. 6 a 10, 13, 21 sobre a limitação ao setor industrial e exclusão do artesanato, art. $8^{\circ}$ sobre o empresário como comerciante;

c. na legislação infortunística, empresa é qualquer organização produtiva que empregue mais de cinco operários. Empresário é sinônimo de empregador, ainda que produza apenas para consumo próprio;

d. na legislação corporativa: (i) na Lei de 3 de abril de 1926 as palavras "empresário" e "empresa" não-aparecem; somente nos (ii) n. 1.130, n. 1251, (iii) n. 150 Código Penal, arts. 330, 331 e (iv) principalmente na Carta del lavoro, mantidas pelo Código Civil, "acolhidas não ligadas a setores particulares da economia, porém abrangendo cada forma de atividade produtiva organizada: agrícola, industrial, comercial, creditícia; nem ligado a especiais dimensões quantitativas, porém envolvendo a grande e média empresa, assim como a pequena

30. Aqui cabe uma nota de rodapé do texto de Asquini: "Não é verdade, portanto, que no regime de economia corporativa do empresário privado, este se transforme em um funcionário público da máquina econômica burocrática do Estado, sem o próprio risco. (...) goza de uma esfera própria de autonomia e o empresário desenvolve sua iniciativa com o próprio risco, o que implica num trabalho criativo e organizado, baseado no lucro, que é sua remuneração. Somente a aplicação do princípio do risco e do proveito não fica mais entregue ao jogo mecânico das leis econômicas em função das condiçōes de concorrência, mas vem moderada politicamente pelo Estado, de acordo com os fins superiores do interesse nacional.(...) [consideram-se] os empregados (...) colaboradores, (...) [o que] pode influir na estrutura jurídica da empresa (...) sobre o aspecto institucional. Neste sentido a empresa corporativa perde aquele caráter individualista e especulativo que tem a empresa na economia liberal, para assumir uma função näo-somente econômica, mas também política e ética." Profili, nota 5. Lembre-se que o nosso regime não é de economia corporativa; portanto, a orientação que prevalece não é a do fenômeno empresarial centrado no papel social do empresário. 
empresa (...) salvo as pequenas empresas com seu estatuto". (Exposição de Motivos do Novo Código).

Em um terceiro momento, a partir dessas constatações, Asquini percebe que, apesar da orientação de aceitar um conceito (baseado nos termos econômicos aqui referidos), não se pode adequar forçosamente o fenômeno econômico em um esquema jurídico unitário, cabendo ao intérprete aclará-lo; respeita-se o nomen iuris dado pelo código, mas se reconhece que existem casos em que a pobreza do vocabulário e a prática da linguagem dão aos significantes "empresa" e "empresário" um significado diverso. Daí nascem os quatro perfis, que são:

a. Perfil Subjetivo empresa como empresário. A organização econômica é considerada pelo seu vértice, o empresário; empresário é sinônimo de empresa. Também pode ocorrer que o vocábulo empresário seja usado para se tratar do estabelecimento, metonímia justificada por o empresário não-estar só na empresa, mas também por ser sua cabeça e alma;

b. Perfil Funcional - empresa como atividade empresarial. Em razão da empresa econômica ser uma organização produtiva que opera por definição no tempo, guiada pela atividade do empresário, é que, sob o ponto de vista funcional ou dinâmico, a empresa aparece como força em movimento, que é a atividade empresarial dirigida a determinado escopo produtivo. Tem uma notável relevância na teoria jurídica da empresa porque serve (1) para se chegar à noção de empresário e (2) da diversidade de atividade (agrícola ou comercial) depende a qualificação do empresário e (3) para a aplicação das normas particulares relativas às relações de empresa;

A atividade resulta (1) de recolher e organizar a força de trabalho e capital para a produção de determinados bens e (2) realizar a troca desses bens ou serviços colhidos ou produzidos. São, por isso, (1) operações fundamentais: (a) passivas- as destinadas à contratação e organização do trabalho e (b) ativas- as operações voltadas às trocas de bens e serviços; (2) acessórias- operações auxiliares das precedentes.

A atividade empresarial se reduz, portanto, em uma série de operações (fatos materiais e atos jurídicos) que se sucedem no tempo, ligadas entre si por um fim comum. A profissionalidade implica no elemento da constância no tempo e seu preordenamento com o fito de lucro, inerente, senão essencial, à empresa econômica. 
Afirmar a existência de atividade empresarial significa afirmar a existência de operações fundamentais da empresa;

\section{c. Perfil Patrimonial e Objetivo empresa como patrimônio aziendal} ou estabelecimento. O exercício da atividade empresarial dá lugar à formação de um complexo de relações jurídicas que tem como centro o empresário (direitos sobre os bens, relações com os empregados, com fornecedores, com clientela). O patrimônio da empresa, portanto, é um distinto do do empresário; daí a regulação do fenômeno da sociedade por ações com um único acionista, a fim de evitar que este meio sirva para superar a personalidade do empresário. A única hipótese que o patrimônio aziendal encontra, no novo Código italiano, disciplina especial como patrimônio separado é aquela da administração judicial prevista no art. 2.091. Asquini, nesse sentido, não-adota a doutrina dominante que chamava de estabelecimento o complexo de bens destinados à atividade empresarial (conceito econômico), mas pensa ser este um complexo de direitos heterogêneos (sobre bens e sobre serviços de empregados e terceiros, que se relacionam à atividade). Nesse sentido, estabelecimento não é universitas rerum;

d. Perfil Corporativo empresa como instituição. Nesse sentido, a empresa é considerada como aquela especial organização de pessoas que é formada pelo empresário, empregados e colaboradores. Empresário, colaboradores, dirigentes, operários, não são apenas uma pluralidade de pessoas ligadas entre si por uma soma de relações individuais de trabalho, cada uma com um fim individual, mas formam um núcleo social organizado em função de um fim econômico comum, no qual se fundem os fins individuais do empresário e os individuais dos colaboradores: obter melhor resultado econômico na produção. A Carta del Lavoro diz isso claramente quando fala de empresário como "organizador de empresa", do empregado como "colaborador ativo da empresa"; a Exposição de Motivos distingue a "organização do trabalho na qual dá lugar a atividade profissional do empresário" da "projeção patrimonial da empresa" O trabalho é sujeito, não-objeto da economia. 31

31. Clara influência da teoria orgânica de v. Gierke: os agrupamentos sociais não são meros amontoados de indivíduos, mas algo distinto deles todos, de natureza superior. No ponto 13, Asquini indica claramente: "a noção de instituição foi elaborada pela ciência do direito público, na Itália especialmente por Romano e, anteriormente, na Alemanha por Gierke e na França por Hauriou", para depois definir instituição como "toda organização de pessoas voluntária ou compulsória embasada em relações de hierarquia e cooperação entre seus membros, em função de um escopo comum.' Por isso, cada instituição cria no seu interior um ordenamento elementar que, ainda que 
Considerar uma organização de pessoas nesse sentido como uma instituição não é o mesmo que personificá-la. A outorga de personalidade jurídica tem o sentido de atribuir a um sujeito diverso dos indivíduos as relações jurídicas externas da organização. ${ }^{32}$

\subsection{Sobre o modelo:}

A análise de Asquini até hoje é uma das mais lembradas, quando se trata de utilizar doutrinariamente o conceito de empresa. Pelo método do autor consegue-se perceber a emergência de uma forma de se captar no universo jurídico como se manifesta o fenômeno da empresa: há um fenômeno inicial, que a doutrina se encarrega de definir, procura-se a forma como o legislador o captou e discute-se semelhanças e diferenças, para indicar qual definição doutrinária se aproxima mais da real, repara-se que a concepção legal adota esta ou aquela doutrina, com estas e aquelas restrições, classifica-se e comprova-se com textos legais.

Acontece que nem na Itália nem em França, origens doutrinárias das nossas concepções jurídicas de empresa, "(...) le législateur n'a pas préalablement défini l'enterprise"," 33 "le législateur a formallement reconnu l'existence de l'entreprise en la nommant mais sens la définir véritablement ni lui reconnaître une personalité physique ou morale qui l'explicite." Assim, continua o autor francês, conferem-se direitos e deveres a pessoas físicas ou morais que têm a qualidade de empresário, senão a lei resultará inaplicável. A. Supiot, afinal, já havia notado que a noção de empresa é uma das mais irritantes que vêm ao jurista na medida em que onde ela aparece é de forma "insaisissable et incontournable. ${ }^{34}$ Mas Jean Hilaire, em seu ensaio sobre a história do conceito, nota que a empresa aparece para o Direito de acordo com as condições de vida à qual ela está vinculada; essa

reconhecido pelo ordenamento jurídico do Estado, é a instituição soberana pode-se considerar como um ordenamento jurídico de grau inferior.

32. Logo em seguida, Asquini trata de definir empresa segundo a teoria de Hauriou da instituição, que coloca três elementos para a gênese do material-conceito de instituição: a. uma idéia-diretriz, b. o poder, e c. as manifestações de comunhão consensual. Para mais: Hauriou, Maurice. La teoría de la instituición y de la fundación. Trad. para o espanhol de Arturo Enrique Sampay, Buenos Aires, Abeledo-Perrot, 1968.

33. Hilaire, Jean. Une histoire du cuncept d'enteprise. In Archives de Philosophie de Droit, 41, 1997.

34. Citado por Robé, J.-Ph. L'entreprise en Droit. In Droit et societé n. 29, 1995. 
observação pode ser transportada para a concepção utilizada por Asquini e para os outros comercialistas italianos.

Poder-se-ia fazer aqui uma revisão de como o conceito aparece para o Direito francês, com base em Hilaire; mais isto não nos interessa no momento. $O$ importante é notar que nosso momento necessita de nova concepção. Nota-se uma evolução no Direito Comercial, primeiro (1) identificando um âmbito a que o Direito Comercial se reporta (somente o da corporação de ofício, na Idade Média), em (2) seguida necessita-se identificar certos atos especiais, já que o Direito Comercial não se restringe a um grupo (no Código napoleônico, adotado pelo nosso Comercial), próximo (3), a definição de uma atividade a que se relaciona a empresa, então (4) um organismo ao qual se imputa essa atividade (concepção do ordenamento corporativo italiano, também em nossa Lei de Falências), agora como instituição (5) (no mesmo, de outra abordagem), só que com a discussão doutrinária no sentido de atribuir ounão a personalidade jurídica a esse tipo de instituição.

Apenas que todas essas evoluções permanecem em nosso ordenamento, assim como se pode identificar que a sociedade brasileira não está inteira, ao mesmo tempo, na mesma situação histórica. Identifica-se o Brasil arcaico junto com o contemporâneo; se o Brasil da regulação dos negócios, via Internet, convive com aquele da sociedade comandita (tipo francês dos séculos XVII e XVIII), que deu a flexibilidade necessária à continuação da atividade empresarial, por "[jouer] à la foi comme moyens de renouveler le capital ou de l'étendre, et encore comme moyen de contrôle par l'aîne au profit de la famille, voire par un groupe de capitalistes, commerçants ou financiers" 35

Cabe agora encontrar o atual momento, nos aproveitando do método de Asquini.

A empresa contemporânea não se coloca apenas no sentido econômico (afinal, se a empresa dependesse apenas das relações econômico-materiais, não necessitaríamos do instituto falência...). Para entendê-la, deve-se contextualizá-la como núcleo para onde confluem elementos econômicos (relativos à produção, matérias-primas, logística dos fatores de produção, todas passíveis de valoração numérico-econômica), sociais stricto sensu (relações de trabalho, de consumo, conflitos), políticas (prevalência de quais interesses, interesses divergentes, subordinação e coordenação) e ideológicas (função social, liberdade de concorrência 
e de iniciativa, igualdade - qual Justiça, a de resultados ou a de chances? Qual Justiça, já que Chaïm Perelman apresenta sete tipos? $)^{36}$ Empresa, no momento préjurídico, é um sistema de relações sociais que se destaca do restante do ambiente de relações, formando um todo único. Quando reguladas pelo Direito, essas relações surgem na forma do conceito de empresa para o Direito. Nesse sentido (e somente nesse), a empresa é um sistema de relações normatizadas, único, um todo, destacável do complexo de relações sociais, e identificável. A evolução da doutrina procura tratar a empresa como pessoa jurídica; nesse sentido, compartilhamos da opinião de Asquini, no sentido de que personificar a empresa tem um sentido diverso dela ser uma instituição (vide supra), substituindo na nossa versão instituição por sistema. ${ }^{37}$

Do ponto de vista pragmático, a noção de empresa é um signo que tem a característica de estabilizar as comunicações, no sentido de ter seu significado preenchido por quem a ele se refere, de acordo com a necessidade; mas, do mesmo modo, corresponde ao uso que aquele que o recebe e entende faz do conceito. $\mathrm{O}$ centro do problema, por conseguinte, está em encontrar a forma como o legislador (emissor normativo) o encara, para então perceber que tipo de aplicação ele pode ter. É essa a razão do debate doutrinário: fixar um modo de como o legislador define a empresa e como ela deve ser entendida para que se apliquem as normas relativas a ela.

\section{Classificações}

Podemos dividir as relações pertencentes ao fenômeno da empresa de vários modos. Entre eles:

I. o citado por nós supra, segundo o tipo preponderante de orientação das relações: (1) econômicas, (2) sociais, (3) política e (4) ideológicas;

II. segundo o âmbito a que se referem, se ambos os pólos da relação pertencem ao sistema ou se um é interno e, o outro, externo.

(1) internas, aquelas que dizem respeito à organização da atividade, nas quais ambos os pólos pertencem ao interior do sistema (logística, papéis e funções, hierarquia e poderes, cultura empresarial), e

36. Ética e Direito, São Paulo, Martins Fontes, 1995.

37. Note-se que não se trata apenas de uma substituição de termos, mas mudança de contexto; achamos correta a opinião de Asquini sob a nossa óptica sistemática. 
(2) externas, aquelas que dizem respeito à relação daquele núcleo social empresa com os outros núcleos, sejam eles a sociedade como um todo ou em pequenos grupos (de consumidores, fornecedores, associações civis), outras empresas ou até Governos (adquirir matérias-primas e vender produtos, com o meio ambiente, com a concorrência e com o consumidor, com o(s) Governo(s), filosofia e imagem).

A partir daí, poderíamos destacar das relações (1) internas,

(A) as que dizem respeito ao empresário, de como ele se organiza:

i) individual ou sociedade?

a. Individual: $o$ que ele pode ou-não fazer, como ele pode fazer, etc;

b. Sociedade: como são os sócios, qual a natureza de sua condição de sócio (incluindo em que ele é sócio, o modo como exerce poderes e competências, se é dono do capital ou dirigente, ou ambos, hierarquias, duração, etc.);

ii) que tipo de atividade;

iii) identidade do empresário;

(2) as que dizem respeito à atividade; como ela se organiza

i) organização das relações de objetos pessoais (estatuto dos trabalhadores, funções, deveres e direitos);

ii) organização das relações de objeto real (propriedade titularidade, usar, fruir, dispor - de bens materiais e imateriais).

Quanto às relações (2) externas:

(A) relações com o Governo: ${ }^{38}$

i) imediatas (relação direta empresa-Governo, no sistema de subordinação tanto de um quanto do outro e coordenação);

ii) mediatas (relação na qual entra um terceiro elemento, como um grupo político, social, econômico, Governo de outro país, instituição supranacional, etc., também nas orientações de coordenação e subordinação de duplo sentido).

(B) relações com a sociedade latu sensu:

i) imediatas:

a) com outros sistemas (outras empresas, associações, etc);

38. Importante lembrar que o Governo nada mais é que um sistema. Aqui, merece tratamento distinto apenas porque apresenta uma relação especial com a empresa, que é de inteira e completa subordinação nas questões de ordem pública e alternância de subordinação e coordenação nas questões de ordem privada. Em tese, com o enfraquecimento do conceito de soberania, a tendência é que a subordinação não seja mais verdade absoluta, assim como o observado por Robé, J.-Ph. L'enteprise en droit. In Droit et Societé n. 29, 1995. 
b) com indivíduos (consumidores individuais, fornecedores, grupos heterogêneos de consumidores e fornecedores cidadãos em geral).

ii) mediatas:

a) com outros sistemas, com mediação do Governo ou de outros sistemas (como Governọs, empresas, associações e organismos internacionais e supranacionais);

b) com indivíduos (na forma de grupos difusos e pessoas individuais);

III. segundo a que momento da vida do fenômeno se refere:

(1) criação,

(2) funcionamento,

(3) dissolução,

O Direito, como estabilizador de relações sociais, não-regula todas as relações que permeiam o fenômeno empresarial. Sendo um tipo de linguagem, na qual as relações de poder são mais pronunciadas, ${ }^{39}$ ele também tem a faculdade de construir a realidade, na medida em que serve de código para a comunicação humana. Quando normatiza determinada relação, indica de que forma ela deve acontecer.

Nesse sentido, cabe verificar como o fenômeno empresarial é regulado pelo Direito. Assumimos aqui um ponto de vista doutrinário para fazê-lo.

Pensando-se na primeira classificação:

4.1. Considerando o tipo preponderante de orientação das relações (1) econômicas, (2) sociais, (3) política e (4) ideológicas:

39. Toda linguagem tem sua forma de poder, dado que é um tipo de relação social, um tipo de comunicação. Nesse sentido, ver Luhmann, Niklas Social sistems. Trad. de John Bednarz, Jr. e Dirk Baecker. Califórnia, Stanford University Press, 1996 e Sociologia do Direito. vs. 1 e 2. Trad de Gustavo Bayer, Rio de Janeiro, Tempo Brasileiro, 1985, Habermas, Jurgen. Between facts and norms: Contributions to a discourse theory of law and democracy. Trad. de William Rehg, Massachusetts, MIT Press, 1996. Teoria do agir comunicacional e Consciência moral e agir comunicativo. Trad. de Guido A. de Almeida, Rio de Janeiro, Tempo Brasileiro, 1989. Para aplicação no Direito, Ferraz Jr., Tércio Sampaio. Introdução ao estudo do Direito: técnica, decisão, dominação, São Paulo, Atlas, 1994. Direito, retórica e comunicação: subsídio para uma pragmática do discurso jurídico, São Paulo, Saraiva, 1997. Teoria da norma jurídica: ensaio de pragmática da comunicação jurídica, Rio de Janeiro, Forense, 1997. Função social da dogmática jurídica. Tese pelo Departamento de Filosofia e Teoria Geral do Direito da FDUSP, 1978. 
Repare nesse excerto da Constituição da República Federativa do Brasil:

Título VII Da Ordem Econômica e Financeira (arts. 170 a 192)

Capítulo I - Dos Princípios Gerais da Atividade Econômica (arts. 170 a 181)

\section{Texto:}

Art. 170 A ordem econômica, fundada na valorização do trabalho humano e na livre iniciativa, tem por fim assegurar a todos existência digna, conforme os ditames da justiça social, observados os seguintes princípios:

I. soberania nacional;

II. propriedade privada;

III. função social da propriedade;

IV. livre concorrência;

$V$. defesa do consumidor;

VI. defesa do meio ambiente;

VII. redução das desigualdades regionais e sociais;

VIII. busca do pleno emprego;

IX. tratamento favorecido para as empresas de pequeno porte constituídas sob as leis brasileiras e que tenham sua sede e administração no País.

* Inciso IX com redação dada pela Emenda Constitucional n. 6, de 15.08.1995 (DOU de 16.08.1995, em vigor desde a publicação).

Parágrafo único. É assegurado a todos o livre exercício de qualquer atividade econômica, independentemente de autorização de órgãos públicos, salvo nos casos previstos em lei.

A primeira observação que pode ser feita: não é única a relação de que se trata no artigo; ele fala em atividade econômica em geral, o que, sob determinado ângulo, pode incluir a atividade empresarial. Se se considera o sistema "empresa" como formado por relações, dentre elas as econômicas, teoricamente as relações econômicas das empresas devem reger-se sob esses princípios. Só que princípios não são apenas postulados de ordem técnica, mas trazem consigo também determinada visão de mundo, determinada ideologia. Por isso, pode-se considerar que, apesar do caráter eminentemente político, essa norma dá consagração a alguns valores, o que exclui outros a eles diretamente contrapostos. Já fizemos essa observação, quando tratamos da chamada "função social da propriedade" mas não sob este prisma 
sistêmico. Em geral, as normas constitucionais têm caráter mais político-ideológico do que econômico ou social. Não dizem como certo aspecto da economia deve ser diretamente, mas como ele não-deve ser - aquilo que Ferraz Jr. chama de codificação fraca -, sendo que a exatidão da orientação da relação deve aparecer em uma norma menos genérica ou na decodificação autorizada. Essa é, na nossa concepção, a diferença entre o que a doutrina constitucional geralmente chama de normas autoaplicáveis e não-auto-aplicáveis: têm caráter marcadamente ideológico (por isso genérico). Ainda assim são normas, o que significa que restringem, cercam, em todo ambiente de comportamentos possíveis, aqueles que estão de acordo com sua orientação. Nesse caso, pode-se saber se determinado comportamento é contrário à norma somente se ele for em demasia noutro sentido; as nuances não são classificáveis nessa lógica.

Atenhamo-nos à noção de empresa. Para nos certificar que tal norma abrange o conceito de empresa, verificamos que há menção específica a um certo tipo delas: a empresa de pequeno porte. Essa referência nos dá certeza de que dentre as relações que pertencem ao sistema da empresa, aquelas que forem econômicas devem ser regidas por esses princípios. Só que não são ideológicos? Ora, mas podem ser positivadas normas que tratem diretamente dos aspectos econômicos, tendo essas de serem interpretadas segundo os princípios. Implicitamente se descobre uma classificação feita pelo ordenamento, para delimitar a relação à qual ele trata: há uma diferença entre pequenas e grandes. Deve-se procurar no ordenamento algo relativo à essa definição genérica: Lei n. 8.864, de 28 de março de 1994:

Estabelece Normas para as Microempresas ME, e Empresas de Pequeno Porte EPP, Relativas ao Tratamento Diferenciado e Simplificado, nos Campos Administrativo, Fiscal, Previdenciário, Trabalhista, Creditício e de Desenvolvimento Empresarial (art. 179 da Constituição Federal).

* Vide a Lei n. 9.317, de 05.12.1996, sobre a matéria.

Capítulo II Da Definição de Microempresa e de Empresa de Pequeno Porte (arts. $2^{\circ}$ e $3^{\circ}$ )

Texto

Art. $2^{\circ}$ - Para os efeitos desta Lei, consideram-se:

I microempresa, a pessoa jurídica e a firma individual que tiverem receita bruta anual igual ou inferior ao valor nominal de duzentas e cinqüenta mil Unidades Fiscais de Referência UFIR, ou qualquer outro indicador de atualização monetária que venha a substituí-la; 
II empresa de pequeno porte, a pessoa jurídica e a firma individual que, não enquadradas como microempresas, tiverem receita bruta anual igual ou inferior a setecentas mil Unidades Fiscais de Referência UFIR, ou qualquer outro indicador de atualização monetária que venha a substituí-la.

$\S 1^{\circ} \mathrm{O}$ limite da receita bruta de que trata este artigo, apurado no período de $1^{\circ}$ de janeiro a 31 de dezembro de cada ano, será calculado considerando-se o somatório das receitas brutas mensais divididas pelos valores das Unidades Fiscais de Referência UFIR vigentes nos respectivos meses.

$\S 2^{\circ}$ No primeiro ano de atividade, o limite da receita bruta será calculado proporcionalmente ao número de meses decorridos entre o mês de constituição da empresa e 31 de dezembro do mesmo ano, desconsideradas as frações de mês.

$\S 3^{\circ} \mathrm{O}$ enquadramento da firma individual ou da pessoa jurídica em microempresa ou em empresa de pequeno porte, bem como o seu desenquadramento, não implicarão alteração, denúncia ou qualquer restrição em relação a contratos por elas anteriormente firmados.

$\S 4^{\circ}$ (Vetado)

Capítulo III Do Registro Especial e Enquadramento (arts. $4^{\circ}$ a $7^{\circ}$ )

Art. $4^{\circ}$ A pessoa jurídica ou a firma individual que, antes da promulgação desta Lei, preencher os requisitos de enquadramento como microempresa ou empresa de pequeno porte, comunicará esta situação ao órgão competente, para fim de registro especial, na forma prevista neste Capítulo.

Art. $5^{\circ}$ Tratando-se de empresa já constituída, o registro será realizado mediante simples comunicação, da qual constarão:

I o nome e demais dados de identificação da firma individual ou da pessoa jurídica e de seus sócios;

II a indicação do registro de firma individual ou do arquivamento dos atos constitutivos da sociedade;

III a declaração do titular ou de todos os sócios de que o volume da receita bruta anual da empresa não excedeu, no ano anterior, os limites fixados nos incisos I e II e no $\$ 4^{\circ}$ do art. $2^{\circ}$ desta Lei, e de que a empresa não se enquadra em qualquer das hipóteses de exclusão do art. $3^{\circ}$ desta Lei. 
Parágrafo único. $O$ registro especial da microempresa e empresa de pequeno porte será feito em conformidade com a legislação em vigor. Lei n. 8.864 de 28.03.1994 DOU 29.03.1994

Art. $6^{\circ}$ Feita a comunicação, e independentemente de alteração do ato constitutivo, a microempresa adotará, em seguida ao seu nome, a expressão "microempresa" ou, abreviadamente, "ME" e a empresa de pequeno porte, a expressão "empresa de pequeno porte" ou "EPP"

Parágrafo único. É privativo de microempresa e de empresa de pequeno porte o uso das expressões de que trata este artigo. Lei $n .8 .864$ de 28.03.1994 DOU 29.03.1994

Art. $7^{\circ} O$ órgão incumbido de registrar as microempresas $e$ as empresas de pequeno porte, conforme o disposto neste Capítulo, comunicará esses registros aos órgãos fiscalizadores da Administração Federal, Estadual $e$ Municipal.

Parágrafo único. Feita a comunicação, os órgãos fiscalizadores procederão à imediata inscrição da microempresa e da empresa de pequeno porte em seus registros.

A lei em tela delimita o conceito de empresa de pequeno porte estabelecendo os requisitos (portanto, normatizando relações). Por exemplo, são normatizações de relações de natureza econômica:

Receita bruta anual igual ou inferior ao valor nominal de duzentas e cinqüenta mil Unidades Fiscais de Referência UFIR, ou qualquer outro indicador de atualização monetária que venha a substituí-la;

de natureza social:

O órgão incumbido de registrar as microempresas e as empresas de pequeno porte, conforme o disposto neste Capítulo, comunicará esses registros aos órgãos fiscalizadores da Administração Federal, Estadual e Municipal.

Parágrafo único. Feita a comunicação, os órgãos fiscalizadores procederão à imediata inscrição da microempresa e da empresa de pequeno porte em seus registros. 
Trata-se aqui de uma ordem para um órgão fiscalizador de como ele deve proceder (note-se que não há relação de imposição ou criação de competência não é de ordem política), cumprir seu papel social. Essa relação é externa à empresa, dela com outro órgão do Estado.

\subsection{Classificação segundo perfis ou núcleos de significação}

Passemos agora para a segunda (II) classificação, que espelha melhor a empresa refletida no Direito nos aspectos que a doutrina clássica indica para delimitá-la. Dizemos isso porque os elementos normativos, dessa forma organizados, dão melhor noção de como o sistema de relações, signo, a que costumamos chamar de empresa, aparece para o Direito.

\subsubsection{A empresa no seu aspecto interno:}

Nem todas as relações que dizem respeito aos aspectos internos das empresas são normatizados pelo Direito; algumas relações não se transformaram em objeto de norma, como a cultura empresarial (entendida como conjunto de valores que pautam a organização da empresa e sua atuação) ${ }^{40}$ se bem que alguns aspectos dessa cultura podem ser abarcados genericamente pelo Direito como, por exemplo, o imperativo de respeito ao consumidor e o de respeito ao meio ambiente. Apesar disso, o conceito de empresa, para o Direito, forma-se gravitando em torno de alguns núcleos de significado.

\subsubsection{Organização do empresário.}

A exemplo disso estão as normas que dizem como deve ser o empresário. O empresário é um papel social no sentido de conjunto de normas que definem um núcleo de relações sociais, núcleo este ao qual se imputam direitos e deveres, poderes, competências e subordinações. Neste sentido, forma um sistema

40. Para algumas noções do assunto, o notabilíssimo Weber, Max. Theory of social and economic organization, Oxford, Henderson and Parkson, 1947 e Basic concepts of sociology, Nova York, Citadel Press, 1962. Para aplicação na teoria da administração de empresas, ver Kwasnicka, Eunice Lacava. Teoria geral da administração: uma síntese, São Paulo, Atlas, 1995 e Introdução à administração, São Paulo, Atlas, 1994. 
único, identificável dentro do complexo de relações sociais reguladas pelo Direito no que tange à empresa. Sendo uma unidade autônoma, apesar de inserido no contexto da empresa (afinal, como dito supra por Ascarelli, é a natureza e o exercício da atividade que qualificam o empresário, não a qualidade do sujeito que define a atividade ele não existe se não-houver a empresa), o empresário deve ter um estatuto jurídico básico. ${ }^{41}$

A doutrina apresenta-o, primeiro, como centro de imputação da vontade jurídica relevante (letra d) da descrição do pensamento de Ascarelli, dando as qualidades dele segundo o Código italiano. Fala-se, em primeiro lugar da dupla característica econômica do empresário: risco e iniciativa, que podem ser ou-não acompanhadas de lucro. Casanova, Ferri e Ascarelli constatam que, para o Direito, identificar ambos é complexo, porque as noções não-entram puras (apenas podem ser deduzidas do Direito em algumas ocasiões, exemplificadas pelo terceiro) e, também, porque implicam numa série de relações que podem ser imputadas a sujeitos distintos na realidade.

Colocam então como pré-requisito da imputação a tipificação: certas relações jurídicas (direitos ou deveres agrupados em feixes) que são características do complexo empresário. É como se ele fosse um organismo, o qual é titular de

41. Considera-se também que todas as relações que têm como um dos pólos o empresário, por conseqüência, o tem a empresa (o empresário é subsistema da empresa, todas as relações que fazem parte dele fazem dela). $O$ inverso não é verdadeiro: existem relações que não-podem ser imputadas ao empresário que o são à empresa; estamos falando de relações sociais genéricas aqui. Só que, como dissemos, nem todas as relações sociais são normatizadas; as que interessam ao Direito têm sempre que ter um dos pólos, por derivação, um indivíduo. Assim, quando da imputação de consequiências jurídicas, necessitamos individualizar um sujeito (ou um grupo deles, identificável cada um de seus elementos) que será um dos pólos da relação. Como as relações analisadas no caso derivam do fenômeno da empresa, isso significa que, nessas condições, qualquer consequiência jurídica imputada àquele (ou àqueles) indivíduos será integrante do fenômeno empresa.

Por exemplo: o princípio da livre concorrência implica em uma série de imperativos, econômicos, sociais, políticos e ideológicos. Esses imperativos se traduzem em uma série de relaçōes. Mas dentre estas, o Direito tutela, grande parte das vezes, apenas as econômicas (algumas sociais, poucas políticas, quase nenhuma ideológica). Por exemplo, livre concorrência significa, positivamente, que não se pode cometer determinadas práticas que impliquem em uma empresa produtora de utensílios de plástico, firmar acordos com todos os fornecedores de matéria-prima para que estes não-vendam para suas concorrentes. Esta é uma relação econômica, o que não-impede que, na empresa Plastic, exista um desejo de cometer esse procedimento "imoral"; se desaparecer a norma objetiva econômica, ela firmará os acordos. Mas da cultura empresarial, outra instância de relações, pode fazer parte determinada concepção que, mesmo que a norma econômica positiva desapareça, ela não o fará concep̧̧ão que é norma moral a qual não tem tutela jurídica. 
direitos e deveres, sendo uno e único. ${ }^{42}$ Daí, pode-se identificar dois níveis de relações: (a) as relações da empresa com o Exterior são imputadas todas a ele, como se ele fosse um único organismo. Só que, para a aplicação do Direito, exige-se que pessoas individuais sejam responsabilizadas pelas consequências jurídicas da atividade empresarial. Assim, existe um segundo nível de relações (b), internas ao fenômeno do empresário, as quais apontam para as pessoas que devem ser diretamente responsabilizadas pelas relações resultantes da existência da empresa.

Enquanto essa implicação é simples de ser tratada nos casos que a doutrina chama de empresários individuais, torna-se mais complexo quando se trata de uma sociedade empresarial ou empresário coletivo. No primeiro caso, uma única pessoa é pólo de todas as relações que dizem respeito ao empresário; no segundo, há uma distribuição dos direitos e deveres entre as diversas pessoas cujas relações fazem parte do sistema empresário.

Por exemplo no caso da alienação de um imóvel. A empresa individual vende o imóvel X por $\mathrm{R} \$ 7$ mil. Não estando o empresário impedido de fazê-lo por nenhuma disposição normativa (da lei, de contrato válido), o ato é válido e pode ter efeitos. Se há algum impedimento, o empresário é responsabilizado e é punido na forma da lei, se for o caso, ou seu ato é anulado. Como todas as relações que fazem parte do núcleo empresário são imputadas a um único indivíduo, não-existe problema neste processo.

Caso diverso é de uma sociedade empresarial. Vejamos o exemplo da "Pequenina Ltda" As relações, num primeiro nível, transcorrem do mesmo jeito (portanto entre empresário e comprador). Mas, num segundo plano, deve-se observar (1) se o ato poderia, segundo o objeto social da empresa, ser válido. Se sim, o passo seguinte (2) é identificar quem poderia ser titular do direito de cometer o ato que dá origem à alienação da propriedade: qualquer um dos sócios? Somente os sóciosgestores? Talvez um dos diretores? Se sim, o ato foi executado pelo indivíduo competente, a relação é válida e a operação gera os efeitos esperados. Se não, é preciso encontrar as normas que dispõem sobre a hipótese conseqüente; dependendo do ordenamento e do contrato social, a venda pode ser considerada nula, inexistente ou anulável; pode implicar ou-não numa sanção extra de cunho penal ou financeiro, segundo a lei, e/ou uma sanção financeira segundo o contrato social, do tipo multa, e

42. Para nós, ele é um subsistema normativo do sistema empresário, que possui uma coesão dada por um estatuto teórico básico, uma estrutura de normas que organiza o repertório de relações sociais positivadas. 
destituição do cargo, por exemplo. Se a resposta da pergunta (1) foi não, cai-se em conseqüências parecidas com o não da pergunta (2).

O titular da relação externa é sempre a sociedade ("Pequenina Ltda" e o indivíduo $\mathrm{N}$ contratam a venda do imóvel $\mathrm{X}$ ). Mas as consequiências jurídicas são imputadas sempre a indivíduo(s) identificável(eis).

Se isto é assim, o que se necessita agora é identificar as normas que fazem parte do empresário. Em primeiro lugar (1), estão as que definem que indivíduos $^{43}$ têm relações normatizadas pertencentes ao núcleo empresário, ou seja, que delimitam o universo de relações que pertencerão ao núcleo, com base no critério de identificação de um dos pólos. Vale fazer a mesma ressalva anterior: os diversos tipos de relações que compõem cada um dos grupos de normas podem ser imputados a uma só pessoa (no caso do empresário individual) ou cada uma a um indivíduo ou vários, diferentes ou-não; por isso Ascarelli diz que deve haver tipificação. Neste sentido, a doutrina e a lei falam em requisitos como:

a. profissionalidade: diz respeito ao (i) status do empresário - tese esta de Casanova; por exemplo a lei da micro e pequena empresa, citada supra. (ii) impedimentos e incompatibilidades relacionados com a situação social e tipo de atividade do indivíduo, identificável na exposição de requisitos de Requião (capacidade, exercício de atos de comércio e profissão habitual). ${ }^{44}$ Ex.: antes da Lei n. 4.121, de 27.08.1962, existia o impedimento de mulheres casadas comerciarem, proveniente do art. $6^{\circ}$ do Código Civil; menores, (incapacidade relativa art. $9^{\circ}$ Código Civil); os da Lei n. 556, de 25.06.1850 (Código Comercial); funcionários públicos e representantes políticos: CF, art. 54, II, Decreto-Lei n. 2.848 de 07.12.1940; também proibições decorrentes do tipo de atividade - art. 55 do Decreto n. 81.771, de 07.06.1978 (Regulamenta a Lei n. 6.507, de 19.12.1977, que dispõe

43. Note bem que os conceitos empresa e empresário são sistemas de relações; significa, em decorrência, que um mesmo indivíduo pode ter (ser um dos pólos de) algumas relações que pertencem ao núcleo empresário, outras que não; mas todas pertencerem ao núcleo empresa. Neste sentido, um presidente pode ter poderes de alienação do patrimônio da empresa (este pertencente ao núcleo empresário), mas também ser assalariado (titular de um direito de crédito contra o empresário, nas condições de contraprestar um determinado serviço - relação externa ao núcleo empresário). A lei traz dificuldades nessa conceituação: Lei n. 5.709 de 07.10.1971 DOU 11.10.1971. Regula a Aquisição de Imóvel Rural por Estrangeiro Residente no País ou Pessoa Jurídica Estrangeira Autorizada a Funcionar no Brasil, e dá outras providências. (Regulamentada pelo Decreto n. 74.965 , de 26.11.1974). Note-se que, enquanto pessoa jurídica diz respeito ao empresário, funcionar é somente imputável à empresa a pessoa jurídica existe ou não-existe, é a empresa que funciona ou-não, no sentido de executar seu objeto social, ou seja, manter as relações sociais a ela impostas.

44. Curso, pp. 79 e ss. 
sobre a Inspeção e a Fiscalização da Produção e do Comércio de Sementes e Mudas, e dá outras providências); estrangeiros - CF arts. 190 e 222, Dec. n. 1.041/1994, arts. $2^{\circ}$ e 33 , Instrução Normativa n. 58 do DNRC; e (iii) modo como ele organiza a atividade de produção (toda a teoria de administração). É importante lembrar que, no caso das sociedades, as proibições recaem sobre os indivíduos competentes a certos atos - se eles não-cumprirem determinados requisitos, não-poderão ser titulares de tais competências e, na forma da lei, se estiverem nessa função, a sociedade empresarial deve ser desqualificada coisa não tão-freqüente, por motivos óbvios. É o ter um papel social definido, no sentido weberiano de idealização. Também existem os casos em que há vedações de funcionamento de empresa, relativas à consecução ou-não de autorização para exercício de atividade. São os casos da Lei n. 4.595, de 31.12.1964, que exige para o funcionamento das instituições (empresas) financeiras autorização do Banco Central para funcionar no País (art. 10); Lei n. 4.728, de 14.07.1965, que exige autorização da CVM para que corretoras de títulos (art. 10); Decreto-Lei n. 73 de 21.11.1963, que exige autorização da Susep para seguradoras, Lei n. 6.360, de 23.09.1976, que submete ao Sistema de Vigilância Sanitária os Medicamentos, Insumos Farmacêuticos, Drogas, Correlatos, Cosméticos, Produtos de Higiene, Saneantes e Outros e exige adequação da empresa a essa vigilância para que funcione;

b. atividade econômica: diz respeito a (i) que tipo de atividade o empresário deverá executar o objeto social e (ii) como ele irá executar ato comercial (ou empresarial, segundo artigo citado quando da exegese). Esse tipo de critério é mais freqüente quando a doutrina trata de sociedades comerciais, nos casos em que alguns dos atos dos indivíduos extrapolam o objeto social da empresa (falase em escopo), o que leva a uma responsabilização individual; também está relacionada à produção de bens. Há na legislação uma série de regulações que dizem respeito aos atos de comércio, no próprio Código Comercial, além de, por exemplo, a ação renovatória. Há a noção de produção, mas mais importante é o desejo de inserir-se no processo econômico como produtor, conquistando mercado; as relações referentes dizem respeito também ao objeto social da empresa;

c. exercício efetivo: refere-se à frequência e ao intuito do empresário quando pratica atos; é mais um índice da profissionalidade, no sentido de assumir seu papel social (portanto ocupar o espaço delimitado por um feixe específico de relações sociais), o agir direcionado pelo e segundo o objeto do contrato social; 
d. lucro (no mínimo intuito): Asquini nos mostra que o lucro surge para o Direito como motivação normal da atividade empreendedora ou remuneração ou prêmio por seu risco e atividade organizatória. Já Ascarelli relaciona lucro como imputação de responsabilidade sobre resultados da atividade empresarial. Casanova diz que lucro não é elemento essencial do empresário, mas da empresa, pois significa sua subsistência.

A questão aparece para o Direito na forma de imputação de resultados da atividade econômica à qual faz parte do conceito de empresa; pode uma empresa não-lucrativa subsistir? Se pode, tem razão de ser? Podemos relacionar o lucro como elemento do conceito de animus ou afectio societas, nos casos de sociedade empresarial; a reunião de pessoas se dá em torno de vários motivos, entre eles uma idéia central, que é a de conseguir lucro em sua atividade, a remuneração por seu investimento, atividade, imobilização de capital. Em sociedades identificadas não mais pelos sócios, mas pelo capital (como as S.As), a falta do lucro é a principal caracterização na jurisprudência do não-cumprimento do fim social (escopo). ${ }^{45} \mathrm{~A}$ companhia deve ser lucrativa e também atender o direito subjetivo do acionista de receber parcela compatível e proporcional ao lucro apurado, sob a forma de dividendos.

Mas a não-observação desse princípio só significa a desagregação do núcleo, quando se transformar em motivo de extinção da afectio societatis. É bom lembrar, neste sentido, que mais da metade das empresas brasileiras cujo empresário é sociedade anônima declaram que juridicamente não-tiveram lucro no exercício de $1998,{ }^{46}$ e nem por isso estão em processo de liquidação. Dado este motivo, o descontentamento (relação orientada ao conflito) pode ser transformado em motivo de dissolução observadas as delimitações legais, como o art. 206, I, c), e II, b), no caso do descumprimento do fim social; assim, um dos sócios pode ser titular de um direito de ação, nesses parâmetros.

Em (2) segundo lugar, estão as que dizem respeito à distribuição de direitos e deveres dentro do núcleo empresário. No caso das firmas individuais todas as funções estão concentradas na figura de uma só pessoa; já nas sociedades de pessoas ou capitais, a organização é complexa e demanda a consulta à regulação

45. Ver Comparato, Fábio Konder. Op. cit.; e Carvalhosa, Modesto. Comentärios à lei das S.A. v. 4, t. I, o comentário ao art. 206, II, b).

46. O jornal O Estado de S. Paulo divulgou na semana de 15 de maio a $1^{\circ}$ de junho de 1999 as repercussões do depoimento do secretário da Receita Federal na CPI dos bancos, confirmando o fato. 
legal e ao contrato social (das sociedades de pessoas) ou ao estatuto (das sociedades de capitais). Não cabe aqui descrevê-las; a nós importa a natureza desse tipo de norma que regulamenta as relações que pertencem ao núcleo empresário. Elas definem a distribuição de competência e imputam consequiências aos indivíduos cujas relações pertencem ao núcleo, de forma a estipular responsabilidades e titularidade de poderes (direitos subjetivos) e deveres.

O objeto social consta do contrato social ou do estatuto, porque é o fator de agregação; é ele que dá sentido ao núcleo de relações sociais chamado empresário, sob a idéia de escopo é construída a figura do empresário. Portanto, faz parte do núcleo empresário.

Podemos definir dois tipos de normas, conforme a natureza da relação regulada: a. as que dizem respeito ao conceito, que a doutrina normalmente chama de iniciativa, o que significa as que definem competências e responsabilidades de agir e gerir a organização; b. as que dizem respeito ao risco, ou a responsabilidade pelo adimplemento das obrigações assumidas pela empresa. São dois tipos de normas altamente dependentes, pois a titularidade de poderes envolve a possibilidade de alienação de direitos patrimoniais da empresa, ligados à responsabilidade patrimonial, e a responsabilidade é definida segundo critérios da função do indivíduo na empresa (posição na organização). Se o lucro é visto como um prêmio pelo risco na doutrina, ele aparece para o Direito como imputação de resultados da atividade ao empresário; é este o sentido dele ser positivo ou negativo (se há prejuízo). Desta forma, concordamos com Ascarelli e não com Casanova, que vê o lucro como elemento da empresa (é elemento da empresa, mas não da forma colocada empresário é subsistema da empresa, não unidade separada); é interessante sua concepção da idéia de lucro para as empresas públicas - o empresário pode ter prejuízo, mas a empresa foi lucrativa porque as benesses sociais foram maiores que as perdas (ela prestou um serviço à sociedade).

No caso da responsabilidade por adimplemento de obrigações patrimoniais, isso acontece deste jeito: a empresa B Ltda., familiar, grande no setor de laticínios, contrai dívida para financiar a compra de um jatinho. A obrigação é firmada entre a empresa, representada pelo empresário $\mathrm{B}$, e o Banco $\mathrm{C}$. $\mathrm{O}$ ato que dá origem ao contrato e o pagamento ficam imputados a quem, no núcleo empresário, tem competência para executar o ato de firmar contrato e quem tem poderes para saldar a dívida com o dinheiro proveniente do caixa. São etapas (1) após consultar a legislação das Ltda. e o contrato social da empresa, descobre-se que o único que 
seria competente para tal é o administrador incumbido de poderes pelos sócios no ato de fundação da empresa (ou na modificação do contrato). Se o contrato foi sim por ele firmado, passa-se a (2) quem tem competência para adimplir no nome da empresa. É o tesoureiro, segundo também o contrato social ele transfere sim a verba da conta da empresa para a do banco. No caso de não ser ele, a relação cai na regulação do Código Civil sobre pagamento (deve-se descobrir se foi executada por terceiro interessado ou-não interessado, com que dinheiro). Se foi outro membro da administração (por exemplo, um sócio não designado como gerente, sem poderes para movimentar a conta da empresa) ele pode sofrer as sanções do contrato social apesar da empresa estar adimplente. Também o sócio, se pagou de forma contrária à lei, responde como pessoa física, não em nome da empresa. No caso de (1) ter sido executado por pessoa não-competente, ela responde também em seu próprio nome. Além disso, deve-se lembrar que a medida da competência em (1) é adequação ao objeto social, qualquer ato que exorbite será de total responsabilidade pessoal do executor do ato.

Neste sentido, a doutrina ${ }^{47}$ apresenta classificações de empresas com base nas características de seu empresário:

a. segundo o objeto de sua atividade (comerciais e civis);

b. segundo as dimensões da atividade da empresa (grandes, médias, pequenas e microempresas);

c. segundo a natureza do empresário (empresa individual ou coletiva);

d. também segundo a natureza, mas em outro aspecto (empresa pública ou privada);

A legislação dá a definição jurídica ou aceita, de forma indireta, algumas dessas divisões:

a. empresa comercial (cujo objeto é dado por um caráter de relações comerciais): Decreto-Lei n. 452 de 01.05.1943 - Consolidação das Leis do Trabalho (arts. $2^{\circ}$ e ss.); Decreto-Lei n. 4.014 de 13.01.1942 - Dispõe sobre as Atividades de Despachantes Aduaneiros e dá outras providências (art. 30); Lei n. 2.180 de 05.02.1954 Dispõe sobre o Tribunal Marítimo (arts. $2^{\circ}$ e ss.) Lei n. 4.154 de 28.11.1962 Dispõe sobre a Legislação de Rendas e Proventos de qualquer Natureza (arts. $3^{\circ}$ e ss.); Decreto-Lei n. 1.248 de 29.11.1972 Dispõe sobre o Tratamento

47. Casanova, Mario. Op. cit., pp. 95 e ss. Ascarelli, Tullio. Op. cit., pp. 242 e ss. Ferri. Op. cit., pp. 59 e ss. Barreto Filho, Oscar. Op. cit., pp. 126 e ss. 
Tributário das Operações de Compra de Mercadorias no Mercado Interno, para o Fim Específico da Exportação, e dá outras providências (arts. $1^{\circ}$ a 14); Decreto-Lei n. 75.572 de 08.04.1975 Promulga a Convenção de Paris para a Proteção da Propriedade Industrial, Revisão de Estocolmo, 1967; Lei n. 6.404 de 15.12.1976 Lei das Sociedades por Ações; Decreto n. 84.934 de 21.07.1980 - Dispõe sobre as Atividades e Serviços das Agências de Turismo, Regulamenta o seu Registro e Funcionamento, e dá outras providências.

Empresa civil (cujo objeto é dado por um caráter de relações civis): Lei n. 3071 de 01.01.1916 - Código Civil (arts. 1.363 a 1.409); Lei n. 4.504 de 30.11.1964 Dispõe sobre o Estatuto da Terra, e dá outras providências, (arts. $1^{\circ} \mathrm{a}$ $5^{\circ}$ ); Decreto-Lei n. 82 de 26.12.1966 Regula o Sistema Tributário do Distrito Federal e dá outras providências. ${ }^{48}$

b. micro e pequena empresa, ver supra a definição legislativa.

Grande empresa: toda que não é pequena.

c. empresa individual (ou firma individual: o empresário se concentra na figura de uma só pessoa): Consolidação das Leis do Trabalho; Lei n. 4.506 de 30.11.1964 Dispõe sobre o Imposto que Recai sobre as Rendas e Proventos de qualquer Natureza; Decreto-Lei n. 1.598 de 26.12.1977 Altera a Legislação do Imposto sobre a Renda; Decreto-Lei n. 1.958 de 09.09.1982 Extingue o Certificado de Regularidade de Situação CRS e o Certificado de Quitação CQ, Reduz os Casos de Exigência de Prova de Quitação para com a Previdência Social, e dá outras providências; Lei n. 8.036 de 11.05.1990 Dispõe sobre o Fundo de Garantia por Tempo de Serviço, e dá outras providências.

Empresa coletiva (uma sociedade de pessoas tem relações pertencentes ao núcleo empresário): todas as que não se tratam das empresas individuais.

d. pública (o núcleo empresário inclui relações de um ente público, com competências ligadas aos conceitos de iniciativa e risco): Decreto-Lei n. 759 de 12.08.1969 Autoriza o Poder Executivo a Constituir a Empresa Pública Caixa Econômica Federal e dá outras providências; Lei n. 5.615 de 13.10.1970 - Dispõe sobre o Serviço Federal de Processamento de Dados (Serpro), e dá outras providências; Lei n. 5.895 de 19.06.1973 Autoriza o Poder Executivo a

48. A noção de empresa civil é dada, na maioria das vezes, como a atividade exercida pela sociedade civil ou pelo indivíduo, de cunho civil. Discussão doutrinária não nos interessa; para mais, ver as obras citadas. 
Transformar a Autarquia Casa da Moeda em Empresa Pública e dá outras providências (arts. $1^{\circ}$ a 13), e muitas outras, como a Petrobrás, Eletrobrás..., todas reguladas com base na Constituição da República Federativa do Brasil

Título VII Da Ordem Econômica e Financeira (arts. 170 a 192)

Capítulo I Dos Princípios Gerais da Atividade Econômica (arts. 170 a 181)

Art. 173 Ressalvados os casos previstos nesta Constituição, a exploração direta de atividade econômica pelo Estado só será permitida quando necessária aos imperativos da segurança nacional ou a relevante interesse coletivo, conforme definidos em lei.

$\S 1^{\circ}$ A lei estabelecerá o estatuto jurídico da empresa pública, da sociedade de economia mista e de suas subsidiárias que explorem atividade econômica de produção ou comercialização de bens ou de prestação de serviços, dispondo sobre:

I sua função social e formas de fiscalização pelo Estado e pela sociedade;

II a sujeição ao regime jurídico próprio das empresas privadas, inclusive quanto aos direitos e obrigações civis, comerciais, trabalhistas $e$ tributários;

III licitação e contratação de obras, serviços, compras e alienações, observados os princípios da administração pública;

IV - a constituição e o funcionamento dos conselhos de administração e fiscal, com a participação de acionistas minoritários;

$V$ os mandatos, a avaliação de desempenho e a responsabilidade dos administradores.

$\S 2^{\circ}$ As empresas públicas e as sociedades de economia mista não poderão gozar de privilégios fiscais não extensivos às do setor privado.

$\S 3^{\circ}$ A lei regulamentará as relações da empresa pública com o Estado e a sociedade.

$\S 4^{o}$ A lei reprimirá o abuso do poder econômico que vise à dominação dos mercados, à eliminação da concorrência e ao aumento arbitrário dos lucros.

$\S 5^{\circ}$ A lei, sem prejuizo da responsabilidade individual dos dirigentes da pessoa jurídica, estabelecerá a responsabilidade desta, sujeitando-a às punições 
compatíveis com sua natureza, nos atos praticados contra a ordem econômica e financeira e contra a economia popular.

e. privada: todas as outras (aliás, pelas emendas constitucionais, a empresa pública tem sua ação regulada pelas mesmas regras da empresa privada; a diferença são os procedimentos relativos ao empresário, que exigem da empresa pública maior transparência o acionista majoritário, teoricamente, é o povo, representado pelo Estado).

\subsubsection{Organização da atividade}

Um segundo tipo de normas são as que dizem como deve ser a atividade empresarial em si. A principal diferença entre as normas que definem o empresário está na teleologia das normas: enquanto o conjunto de normas que regula a organização e definem o empresário para o Direito têm como idéias unificadoras os conceitos de iniciativa e risco, ${ }^{49}$ tendo, portanto, um caráter nitidamente relacionado com o movimento, as normas que regulam a atividade pautam-se pela necessidade de consecução de estabilidade. Elas criam uma situação de continuidade, corrigindo conflitos que podem encerrar a atividade empresarial.

A própria noção de risco entra em confronto direto com a de atividade; enquanto o corolário positivo do risco é o lucro, o da atividade é a continuidade; ao inverso, o negativo do risco é o prejuizo, enquanto o da atividade é a cessação. Quanto maior o risco, maior o lucro, mas também o prejuízo; o benefício maior da atividade é a permanência no mercado, menor é o encerramento. Neste sentido, as relações que preenchem o conceito de atividade têm como escopo a harmonia de interesses desiguais (soma zero), enquanto as relações dos conceitos de risco e iniciativa no direcionamento é no sentido único da maior vantagem (soma maior que zero) - o empresário move-se para ganhar, a atividade luta para permanecer.

Essa constatação leva a um diferente tipo de interpretação das regras relacionadas a cada conceito; enquanto as normas relativas às relações colocadas, como do conceito de empresário, devem ser entendidas de modo a sempre observar

49. Note bem, estes são conceitos que facilitam a utilização prática, os quais resumem um conjunto de relações sociais normatizadas: eles não-aparecem diretamente para o Direito, pois são construções doutrinárias. 
o interesse que leve à maior vantagem, as que regulam a atividade devem ser vistas sob a óptica da maior estabilidade. $O$ interesse público, desse modo, é mais marcante na atividade do que na iniciativa está aí a razão de se encontrar o princípio da função social da propriedade e da livre iniciativa: os direitos de uso, disposição e conservação da coisa devem ser vistos sob a óptica da harmonia e os de risco, sob a óptica do lucro (positivo ou negativo).

Vistas assim, as relações que compõem o núcleo da atividade são basicamente de duas ordens: (i) uma cujo objeto é pessoal e (ii) outra cujo objeto é real. A doutrina mais moderna agrupa esses dois tipos de relações debaixo do conceito de estabelecimento comercial, e considera ora como conjunto de coisas que o empresário se utiliza para exercer sua atividade, ora como conjunto de direitos sobre aquilo que o empresário utiliza, incluindo aí direitos reais e (há discussão) e obrigacionais. Formam, portanto, o patrimônio aziendal ou fazenda da empresa. Preferimos utilizar o conceito de subsistema e núcleo, porque os elementos normativos formam um repertório e também uma estrutura em que se organiza esse repertório no conceito jurídico de empresário não são mero conjunto ou amontoado de elementos.

O núcleo estabelecimento comercial é formado por direitos e deveres que pertencem ao núcleo atividade. Deste fazem parte as relações de objeto real (em si ou legalmente considerado, como direitos sobre marcas e patentes, invenções e tecnologias, imagens), relações de objeto pessoal (prestações de trabalho fazer), relações de organização da atividade.

i) cujo objeto é o comportamento de uma pessoa (ou várias) em si considerado:

Dessa classificação fazem parte as divisões de funções, o código de conduta, as relações trabalhistas (direitos e deveres); o objeto da atividade é parte do núcleo empresário - ele não importa à atividade considerada em si, mas é identificador do empresário; as relações reunidas sob o signo de objeto social não fazem parte do estabelecimento.

As relações trabalhistas têm como pólos (lembre-se: são internas ao fenômeno empresa, ambos os pólos da relação devem pertencer ao sistema empresa) o empresário e os trabalhadores; dependendo de como o Direito considera estes últimos (se a ênfase da organização deles é dada no aspecto corporativo empregados vistos como um órgão da empresa, um único corpo, assim como empresário ou no aspecto individual - empregados vistos na sua individualidade), 
percebe-se a ideologia dominante no ordenamento. O ordenamento italiano (que inspirou também o brasileiro), por causa da concepção de função social a que os indivíduos estavam adstritos, traz uma concepção corporativista. A profissão era demarcada pelos direitos trabalhistas. No nosso ordenamento ainda persistem ranços dessa concepção, mas se vê uma tendência a mitigá-los.

A disciplina das relações de trabalho acaba por ser considerada de caráter publicístico, dada a necessidade de reequilíbrio de forças; são chancelas de caráter indisponível. É sempre importante lembrar que nem todas as relações que dizem respeito ao Direito do Trabalho são constituintes do conceito de empresa; apenas aquelas em que um dos pólos é o empresário portanto internas ao fenômeno. São exemplos: arts. $4^{\circ}$ e $6^{\circ}$ do Decreto n. 423 de 12.11.1935 Promulga as Convenções da OIT n. 5, sobre a Idade Mínima de Admissão nos Trabalhos Industriais, e n. 6, sobre o Trabalho Noturno dos Menores na Indústria; art. $2^{\circ}$ do Decreto n. 1.361 de 12.01.1937 Promulga a Convenção Concernente à Indenização das Moléstias Profissionais (revista em 1934), Firmada por Ocasião da $18^{a}$ Seção da Conferência Geral da Organização Internacional do Trabalho, reunida em Genebra, a 4 de junho de 1934; art. $1^{\circ}$ do Decreto n. 3.233 de 03.11.1938 - Promulga a Convenção relativa ao Emprego das Mulheres nos Trabalhos Subterrâneos nas Minas de qualquer Categoria, firmada em Genebra, a 18 de julho de 1935, por ocasião da $19^{\mathrm{a}}$ Sessão da Conferência Internacional do Trabalho, que se reuniu na mesma cidade, de 4 a 25 de junho de 1935; arts. $2^{\circ} 10,13,36,40,47$, e ss. do Decreto-Lei n. 5.452 de 01.05.1943 Consolidação das Leis do Trabalho; Lei n. 6.019 de 03.01.1974 - Dispõe sobre o Trabalho Temporário nas Empresas Urbanas, e dá outras providências; cap. II da Decreto n. 73.841 de 13.03.1974 Regulamenta a Lei n. 6.019, de 3 de janeiro de 1974, que dispõe sobre o Trabalho Temporário; Decreto n. 1.254 de 29.09.1994 Promulga a Convenção n. 155, da Organização Internacional do Trabalho, sobre Segurança e Saúde dos Trabalhadores e o Meio Ambiente de Trabalho, concluída em Genebra, em 22 de junho de 1981; art. 27, II, da Lei n. 9.069 de 29.06.1995 Dispõe sobre o Plano Real, o Sistema Monetário Nacional, Estabelece as Regras e Condições de Emissão do Real e os Critérios para Conversão das Obrigações para o Real, e dá outras providências; art. $1^{\circ}$ da Lei n. 9.477 de 24.07.1997 - Institui o Fundo de Aposentadoria Programada Individual FAPI e o Plano de Incentivo à Aposentadoria Programada Individual, e dá outras providências. 
A obrigação básica é a do empregado prestar um serviço contra o pagamento de uma quantia em dinheiro pela empresa. Dessa relação sobrevem uma série de outras, entre elas a necessidade de pagar contribuições sociais, de dar condições de trabalho dignas, etc., por parte do empresário, e de cumprir o número de horas acordado, não-faltar, etc., por parte do empregado. Por esses exemplos se vê a busca por uma contemporização de interesses, com reequilíbrio da parte mais fraca. São relações privadas reguladas por princípios de ordem pública indisponíveis. Esses direitos de crédito e ônus (encargos, deveres) fazem parte, portanto, do estabelecimento;

ii) cujo objeto é um comportamento de uma pessoa (ou várias) em relação a um objeto: são créditos ou débitos, tendo como objeto uma coisa, que fazem parte do patrimônio da empresa, ou uma prestação de serviço ou trabalho. São direitos de propriedade sobre bens, utilizados na atividade, que segundo os negócios do empresário podem ser dispostos, ou de propriedade de obrigações de fazer e não fazer, transferidos ou fruídos. Neste caso, não há muita discussão doutrinária; para o Direito, apenas relações jurídicas devem fazer parte do estabelecimento, não a coisa em si considerada.

\subsubsection{As relações externas:}

São relações do núcleo empresa com elementos exteriores. O processo de individualização, no caso das sociedades (núcleos complexos), já foi explicado. Resta aqui tratar dos casos que essas relações são normatizadas:

\subsubsection{Relações com o Governo}

As mais importantes são as (i) imediatas de ordem tributária: as empresas pagam impostos (dever de adimplência) e podem receber incentivos fiscais (direito de crédito), por exemplo. No primeiro caso, é uma relação de subordinação. No segundo, de coordenação - por isso, para que se faça cumprir incentivos específicos, é necessário firmar contratos nos quais as partes se obrigam a deveres.

Não se pode generalizar os objetivos de uma empresa ao tratar com o Governo; têm natureza diversa, sendo que nas regras de interpretação deve ser identificado o que é dominante: a busca da estabilidade ou da vantagem do empresário. 
As relações Governo-empresa também podem ser (ii) mediadas por um órgão supranacional, como uma câmara de comércio, ou a OMC. Neste caso, também são de coordenação, já que o que acontece é um contrato que deve ser observado.

\subsubsection{Relações com a sociedade}

A ordem jurídica chancela certas relações sociais que têm como pólos a empresa e determinados grupos ou indivíduos, impondo comportamentos específicos. Essas relações podem ser de duas ordens:

\subsubsection{Imediatas}

a. com outros sistemas organizados. É o caso das relações de empresas com fundações por elas mantidas, com sindicatos ou organizações patronais, com partidos políticos. Exemplos: a Lei Eleitoral, que fixa todo ano as regras de contribuição das pessoas jurídicas para a campanha política; Decreto-Lei n. 5.452 de 01.05.1943 - Consolidação das Leis do Trabalho:

Art. 540 A toda empresa ou individuo que exerçam, respectivamente, atividade ou profissão, desde que satisfaçam as exigências desta Lei, assiste o direito de ser admitido no Sindicato da respectiva categoria, salvo o caso de falta de idoneidade, devidamente comprovada, com recurso para o Ministério do Trabalho.

Decreto n. 61.843 de 05.12.1967 - Aprova o Regulamento do Serviço Nacional de Aprendizagem Comercial (Senac) e dá outras providências.

I) com indivíduos ou grupos difusos, como consumidores, concorrentes e fornecedores. Nesses casos, o que se busca é o reequilíbrio das relações, corrigindo distorções principalmente do mercado, tendo em vista o aspecto de poder econômico que as empresas exercem sobre outros núcleos sociais. Pode-se identificar dois tipos de pólos secundários das relações: $1^{\circ}$ o mercado (afinal nãoexiste empresa que não tenha relações com o mercado) e $2^{\circ}$ outros tipos de indivíduos e grupos sociais da sociedade civil. Classifica-se aqui assim:

$1^{\circ}$ Se o outro pólo das relações é o mercado e: 
a. o princípio tutelado mais importante é o de livre iniciativa, ${ }^{50}$ é direito de concorrência, que é aplicável às relações desde as de competição entre empresas até relações de fornecimento em nichos específico (não são relações de consumo, que são as mais importantes nesse caso, mas o resultado de concentração econômica e monopólio das compras que algumas empresas têm em determinados nichos). Ex.: Decreto n. 93.962 de 22.01.1987 - Promulga o Acordo relativo à Interpretação e Aplicação dos arts. $6^{\circ}, 16$ e 23 do Acordo Geral sobre Tarifas Aduaneiras e Comércio (GATT), e dá outras providências; Decreto n. 1.745 de 13.12.1995 - que Institui a SDE e o CADE; Lei n. 9.427 de 26.12.1996 - Institui a Agência Nacional de Energia Elétrica ANEEL, Disciplina o Regime das Concessões de Serviços Públicos de Energia Elétrica e dá outras providências; Decreto n. 2.521 Dispõe sobre a exploração, mediante permissão e autorização, de serviços de transporte rodoviário interestadual e internacional de passageiros e dá outras providências; Cap. IX Seç. VII do Decreto n. 2.594 de 15.05.1998 Regulamenta a Lei n. 9.491, de 9 de setembro de 1997, que dispõe sobre o Programa Nacional de Desestatização e dá outras providências; Lei n. 4.137, de 10.09.1962 e Decreto n. 93.083 de 07.08.1986 e Lei n. 8.884 de 11.06.1994 dispõem sobre o Conselho Administrativo de Defesa Econômica, e dá outras providências.

b. o princípio tutelado mais importante é o da proteção do consumidor, é Direito do Consumidor. Podem ser titulares de direitos de consumidor tanto pessoas individuais, quanto pessoas coletivas. Ex.: Lei n. 8.078 de 11.09.1990 Código de Proteção e Defesa do Consumidor, regulamentado pelo Decreto n. 2.181 de 20.03.1997 Dispõe sobre a Organização do Sistema Nacional de Defesa do Consumidor SNDC, Estabelece as Normas Gerais de Aplicação das Sanções Administrativas Previstas na Lei n. 8.078, de 11 de setembro de 1990, Revoga o Decreto n. 861, de 9 de julho de 1993, e dá outras providências; e Ex.: Lei n. 7.347 de 24.07.1985 - Disciplina a Ação Civil Pública de Responsabilidade Por Danos Causados ao Meio Ambiente, ao Consumidor, a Bens e Direitos de Valor Artístico, Estético, Histórico, Turístico e Paisagístico (Vetado) e dá outras providências.

50. Giuseppe Guizzi tem um artigo muito bom sobre a concepção de empresa para a lei antitrust em comparação com a da União Européia, e o Código Civil. Chega a conclusões diferentes das nossas, por se manter fiel às classificações de Asquini trata o fenômeno de concentração sob a óptica do perfil empresário, mas adicionando variáveis da atual concepção de concorrência portanto se livrando em parte do ranço corporativista. Vide Il concetto di impresa tra Diritto Comunitario, legge antitrust e codice civile. In Rivista del Diritto Commerciale, n. 3-4 anno 1993. 
Art. $5^{\circ}$ - A ação principal e a cautelar poderão ser propostas pelo Ministério Público, pela União, pelos Estados e Municípios. Poderão também ser propostas por autarquia, empresa pública, fundação, sociedade de economia mista ou por associação que:

I esteja constituída há pelo menos um ano, nos termos da lei civil;

II inclua entre suas finalidades institucionais a proteção ao meio ambiente, ao consumidor, à ordem econômica, à livre concorrência, ou ao patrimônio artístico, estético, histórico, turístico e paisagístico;

$2^{\circ}$ Se o outro pólo é a sociedade civil, não-identificada como mercado e:

a. o interesse tutelado é o meio ambiente, é direito empresarial ambiental. Ex. Decreto n. 94.075 de 05.03.1987 Dispõe sobre o Prazo de Isenção do Imposto sobre a Renda para os Empreendimentos Agrícolas e Industriais nas Áreas de Atuação da Superintendência do Desenvolvimento da Amazônia Sudam e da Superintendência do Desenvolvimento do Nordeste Sudene.

Art. $3^{\circ}$ A fruição da isenção fica condicionada à observância, pela empresa beneficiária, dos dispositivos da legislação trabalhista e social e das normas de proteção e controle do meio ambiente, podendo a Sudam e a Sudene, a qualquer tempo, verificar o cumprimento do disposto neste artigo.

Decreto-Lei n. 2.452 de 29.07.1988 Dispõe sobre o Regime Tributário, Cambial e Administrativo das Zonas de Processamento de Exportação (ZPE) e dá outras providências.

Art. 12 As importações e exportações de empresa autorizada a operar em ZPE estarão sujeitas ao seguinte tratamento administrativo:

I será dispensada a obtenção de licença ou autorização de órgãos federais, com exceção dos controles de ordem sanitária, de interesse da segurança nacional e de proteção do meio ambiente, vedadas quaisquer outras restrições à produção, operação, comercialização e importação de bens e serviços que não as impostas por esta Lei; 


\section{Decreto n. 96.759 de 22.09.1988 DOU 23.09.1988}

\section{Art. $2^{\circ}$ Compete ao CZPE:}

I traçar a orientação superior da política das Zonas de Processamento de Exportação - ZPE, considerados os seguintes aspectos:

b) observância das normas relativas ao meio ambiente;

Lei n. 7.802, de 11.07.1989 e Decreto n. 98.816 de 11.01.1990 Dispõe sobre a Pesquisa, a Experimentação, a Produção, a Embalagem e Rotulagem, o Transporte, o Armazenamento, a Comercialização, a Propaganda Comercial, a Utilização, a Importação, a Exportação, o Destino Final dos Resíduos e Embalagens, o Registro, a Classificação, o Controle, a Inspeção e a Fiscalização de Agrotóxicos, seus Componentes e Afins, e dá outras providências; Decreto n. 440 de 06.02.1992 Promulga o Acordo Relativo à Conferência das Nações Unidas sobre Meio Ambiente e Desenvolvimento, entre o Governo da República Federativa do Brasil e as Nações Unidas; Decreto n. 783 de 25.03.1993 Fixa o Processo Produtivo Básico para os Produtos Industrializados na Zona Franca de Manaus, e dá outras providências; Lei n. 7.347 de 24.07.1985.

Art. $5^{\circ}$ - A ação principal e a cautelar poderão ser propostas pelo Ministério Público, pela União, pelos Estados e Municípios. Poderão também ser propostas por autarquia, empresa pública, fundação, sociedade de economia mista ou por associação que:

I esteja constituída há pelo menos um ano, nos termos da lei civil;

II - inclua entre suas finalidades institucionais a proteção ao meio ambiente, ao consumidor, à ordem econômica, à livre concorrência, ou ao patrimônio artístico, estético, histórico, turístico e paisagístico;

b. o interesse tutelado é outro também tido como difuso. Ex.: Lei $\mathrm{n}$. 7.347 de 24.07.1985, no já citado art. $5^{\circ}$, inciso II:

II inclua entre suas finalidades institucionais a proteção ao meio ambiente, ao consumidor, à ordem econômica, à livre concorrência, ou ao patrimônio artístico, estético, histórico, turístico e paisagístico; 


\subsubsection{Mediatas}

Relações que incluem um terceiro núcleo mediador entre empresa e os núcleos sociais ou individuais. Também podem ser divididas em núcleos organizados e indivíduos (ou grupos difusos). As mais importantes são aquelas nas quais o mediador é um órgão supranacional, como a ONU, a OMC, a ICC.

\subsection{Classificação segundo a "vida" da empresa}

O terceiro (III) tipo de classificação das relações normadas tem como critério a que ponto da vida da empresa elas se referem; Ferri retém a noção intuitivamente quando diz que a empresa conserva por certo tempo o impulso recebido, mas esse se dilui no funcionamento do seu cotidiano. Para nomeá-las, recorrem a uma analogia com a vida da pessoa física, vista pelo Direito. São três os grupos:

A) nascimento: normas que dizem respeito ao início da tutela jurídica do núcleo. Dão os requisitos e condições formais em que aquelas relações sociais formam para o Direito um núcleo-empresa. Incluem registro, habilitação, formas de sociedades dirigentes, tipos de atividades permitidas;

B) atividade: normas que regulam com a empresa já viva. São a maioria;

C) morte: normas que regulam a dissolução da empresa e apuração dos haveres. É o caso da lei de falência, por exemplo.

A cada uma dessas fases se articula um núcleo normativo como preponderante; nelas deve prevalecer um sentido. Ex.: no momento de nascimento da empresa, o preponderante é o empresário (as normas aplicáveis neste momento devem ser observadas em função de facilitar a livre-iniciativa); na morte, a atividade (as normas aplicáveis devem ser interpretadas no sentido de fazer com que a empresa se perpetue, na medida do possível). 


\section{Conclusão}

Neste trabalho, buscou-se:

1. As várias formas como a doutrina apresenta o fenômeno empresa;

2. Apresentação e adequação do método de Asquini, para tratar do fenômeno;

3. Fazer apontamentos para uma nova definição jurídica do conceito, a partir da concepção do Direito como um normatizador de relações sociais;

4. Fazer classificações doutrinárias das normas.

A partir dessas classificações, como em Asquini, podem emergir alguns perfis de empresas, aqui agora entendidos como sistemas de normas, internos ao sistema empresa, mas que podem ser destacados do todo (para efeitos de estudo) por possuírem um repertório e uma estrutura, o que permite a identificação de núcleos de significação. As normas que constróem o fenômeno empresa para o Direito devem ser interpretadas segundo princípios distintos do resto do sistema; da mesma forma, cada um dos perfis, além de a interpretação das normas que os constróem ser feita seguindo aquelas que regem a da interpretação das relações da empresa, tem sua particularidade e, portanto, normas interpretativas próprias.

Deve-se conferir a que perfil pertencem, estabelecer qual o estatuto básico que dá unidade a este perfil (que princípios são preponderantes), definir o interesse (a orientação do comportamento) que prevalece e, então, se as relações são de (i) coordenação ou (ii) subordinação. Só aí aplicar as normas referentes ao caso prático.

Aqui apresentam-se os seguintes perfis:

I. Nas relações internas:

a. empresa como núcleo empresário (item 4.2.1.1.);

b. empresa como núcleo atividade (item 4.2.1.2);

(i) empresa como sistema de relações empregatícias;

(ii) empresa como sistema de direitos de propriedade; (estabelecimento)

II. Nas relações externas:

c. Relações com o Governo (4.2.2.1):

(i) empresa como sistema de relações fiscais; 
d. Nas relações com a sociedade (4.2.2.2):

$1^{\circ}$ Relações com mercado:

a. empresa como sistema de relações de concorrência;

b. empresa como sistema de relações de consumo;

c. empresa como sistema de relações de parceira e cooperação;

$2^{\circ}$ empresa como sistema de relações de cidadania (meio ambiente e direitos difusos)..$^{51}$

Esses perfis devem ser lidos não na forma apresentada por Asquini, de facetas de um mesmo fenômeno, mas como sistemas de normas, núcleos de significados, os quais têm autonomia - e, por isso, regras e significados próprios.

5. Além disso, as normas que formam o fenômeno da empresa para o Direito podem ser organizadas de outros modos, de acordo com a utilização. A primeira classificação apresentada serve para se discutir sobre que aspecto determinada norma vai incidir, entendendo, assim, a que princípios constitucionais ela deve obedecer: se da ordem econômica, da ordem social, da ordem política, ou se aos princípios ideológicos difusos pelo texto constitucional (interpretação axiológica).

6. A última classificação de normas serve para se verificar quais normas são preponderantes àquele momento da empresa (uma interpretação teleológica).

São Paulo, março de 1999.

Bibliografia

ASCARELLI, Tullio. Corso de Diritto Commerciale. $3^{\mathrm{a}}$ ed., Milano, 1962.

ASQUINI, Alberto. Profili d'Impresi. In Rivista de Diritto Commerciale, n. 1, v. XII, 1943.

BARRETO FILHO, Oscar. Teoria do estabelecimento comercial. São Paulo, Max Limonad, 1969.

51. Cabe observar que o último item tem valor meramente teórico; as disposições a respeito da noção de cidadania nunca foram colocadas em respeito às atividades empresariais, sendo que o estatuto teórico deste perfil parece pouco delineado. Na maioria das vezes, as normas que dizem respeito ao "comportamento cidadão" são interpretadas como meramente econômicas, já que implicam em multas ou perda de incentivos fiscais. Pensamos que não, baseado na experiência de outros países, como Alemanha (a legislação defendida pelos "Verdes" acaba por tomar um aspecto sistemático próprio, formando um autêntico sistema que encontra projeções sobre aspectos da empresa) e EUA. 
BRACCO, Roberto. L'impresa nel sistema de Diritto Commerciale, 1960, n. 47.

BULGARELLI, Waldírio. Tratado de direito empresarial, São Paulo, Atlas, 1995.

CARNELUTTI, Francesco. Sulle nuove posizione del Diritto Commerciale, in Rivista de Diritto Commerciale, 1942, 1.

CARVALHOSA, Modesto. Comentários à Lei das S.A. v. 4, t. I, o comentário ao art. 206, II, b).

CASANOVA, Mario. L'imprese commerciali, Torino, Editrise Torinese, 1962.

COMPARATO, Fábio Konder. Estado, empresa e função social. In RT, v. 732, out. 1996.

DANTAS, Francisco W. L. Lineamentos jurídicos da empresa e o Código do Consumidor. In RT, v. 67, set. 1991.

FERRARA JR., F La teoria giuridica dell'azienda, Firenze, Castelaccio, 1945.

FERRAZ JR., Tércio Sampaio. Introdução ao estudo do Direito: técnica, decisão, dominação, São Paulo, Atlas, 1994.

pragmática do discurso jurídico, São Paulo, Saraiva, 1997.

Direito, retórica e comunicação: subsídio para uma Teoria da norma jurídica: ensaio de pragmática da comunicação jurídica, Rio de Janeiro, Forense, 1997

Função social da dogmática jurídica. Tese pelo Departamento de Filosofia e Teoria Geral do Direito da FDUSP, 1978.

FERREIRA, Waldemar. Tratado de Direito Comercial. VI, n. 1.226.

FERRI, Giuseppe. Manuale de Diritto Commerciale, Torino, 1960.

FRANCO, Vera Lúcia de Mello. Lições de Direito Comercial - Teoria Geral do Direito Comercial, São Paulo, Maltese, 1995.

GHIDINI, Mario. Disciplina giuridica dell'impresa, 1950.

GHIRON, Mario. L'imprenditore, l'impresa e l'azienda, Turim, n. 1, p. 4. s.d.

GIERKE, Otto Von. La naturaleza de las associaciones humanas. Discurso proferido no ato de posse ao Reitorado da Universidade de Berlim em 15 de outubro de 1902.

GUIZZI, Giuseppe. Il concetto di impresa tra diritto comunitario, legge antitrust e codice civile. In Rivista del diritto commerciale, ns. 3-4, anno 1993. 
HABERMAS, Jurgen. Between facts and norms: Contributions to a discourse theory of law and democracy. Trad. de William Rehg. Massachusetts, MIT Press, 1996.

Rio de Janeiro, Tempo Brasileiro, 1989.

Consciência moral e agir comunicativo. Trad. de Guido A. de Almeida. Rio de Janeiro, Tempo Brasileiro, 1989.

HAURIOU, Maurice. La teoría de la instituición y de la fundación. Trad. para o espanhol de Arturo Enrique Sampay. Buenos Aires, Abeledo-Perrot, 1968.

HEILBRONER, Robert. A história do pensamento econômico. Trad. de Teresinha M. Deutsch. São Paulo, Nova Cultural, 1996.

HILAIRE, Jean. Une histoire du cuncept d'enteprise. In Archives de Philosophie de Droit, 41, 1997.

KWASNICKA, Eunice Lacava. Teoria geral da administração, uma síntese, São Paulo, Atlas, 1995.

Introdução à administração, São Paulo, Atlas, 1994.

LUHMANN, Niklas Social sistems. Trad. de John Bednarz, Jr. e Dirk Baecker. California, Stanford University Press, 1996.

Sociologia do Direito. vs. 1 e 2. Trad. de Gustavo Bayer. Rio de Janeiro, Tempo Brasileiro, 1985.

MENDONÇA, J. X. Carvalho de. Tratado de Direito Comercial brasileiro, Rio de Janeiro, Freitas Bastos, 1945.

MOSSA, Lorenzo. Trattato del nuovo Diritto Commerciale, Padova, Cedam, 1958.

OLIVEIRA, Jorge Rubem Folena de. Desenvolvimento da teoria da empresa e o fim da distinção entre sociedades civis e comerciais. In Boletim Legislativo Adcoas, 1997, n. 4, 10 de fevereiro.

PERELMAN, Chaïm. Ética e Direito, São Paulo, Martins Fontes, 1995.

REALE, Miguel. Exposição de Motivos do Projeto de Código Civil, Brasília, Ed. do Senado, 1989. Apud Jorge Rubem Folena de Oliveira.

REQUIÃO, Rubens. Curso de Direito Comercial. v. 1. São Paulo, Saraiva, 1998.

ROBÉ, J.-Ph. L'enteprise en Droit. In Droit et Societé, n. 29, 1995.

SANTORO-PASSARELLI, Francesco. L'impresa nel codice civile, in Rivista de Diritto Commerciale, 1942, I, p. 390. 
SANTOS, Theophilo Azeredo dos. Comercialidade das sociedades de objeto civil, fins econômicos e lucrativos. In Caderno Especial, n. 236, da Associação dos Bancos do Estado do Rio de Janeiro.

VERÇOSA, Haroldo Malheiros. Ato de comércio. Mercancia. Matéria de Comércio. Comerciante. In Revista de Direito Mercantil, n. 47.

WALD, Arnoldo. O espírito empresarial, a empresa e a reforma constitucional. In Revista de Direito Mercantil, Industrial, Econômico, Financeiro, n. 98, abriljunho 1995.

WEBER, Max. Theory of social and economic organization, Oxford, Henderson and Parkson, 1947. . Basic concepts of sociology, Nova York, Citadel Press, 1962. 